\title{
THE WATER FOOTPRINT OF
}

COTTON CONSUMPTION

September 2005 



\title{
THE WATER FOOTPRINT OF COTTON CONSUMPTION
}

\author{
A.K. Chapagain \\ A.Y. HOEKSTRA \\ H.H.G. SaveniJe \\ R. GAUTAM
}

September 2005

Value of Water Research Report Series No. 18

UNESCO-IHE DELFT

P.O. BOX 3015

2601 DA DELFT

The NetherLANDS
Contact author:

Arjen Hoekstra

E-mail a.y.hoekstra@utwente.nl 



\section{Value of Water Research Report Series}

(Downloadable from http://www.waterfootprint.org)

1. Exploring methods to assess the value of water: A case study on the Zambezi basin.

A.K. Chapagain - February 2000

2. Water value flows: A case study on the Zambezi basin.

A.Y. Hoekstra, H.H.G. Savenije and A.K. Chapagain - March 2000

3. The water value-flow concept.

I.M. Seyam and A.Y. Hoekstra - December 2000

4. The value of irrigation water in Nyanyadzi smallholder irrigation scheme, Zimbabwe.

G.T. Pazvakawambwa and P. van der Zaag - January 2001

5. The economic valuation of water: Principles and methods

J.I. Agudelo - August 2001

6. The economic valuation of water for agriculture: A simple method applied to the eight Zambezi basin countries J.I. Agudelo and A.Y. Hoekstra - August 2001

7. The value of freshwater wetlands in the Zambezi basin

I.M. Seyam, A.Y. Hoekstra, G.S. Ngabirano and H.H.G. Savenije - August 2001

8. 'Demand management' and 'Water as an economic good': Paradigms with pitfalls

H.H.G. Savenije and P. van der Zaag - October 2001

9. Why water is not an ordinary economic good

H.H.G. Savenije - October 2001

10. Calculation methods to assess the value of upstream water flows and storage as a function of downstream benefits I.M. Seyam, A.Y. Hoekstra and H.H.G. Savenije - October 2001

11. Virtual water trade: A quantification of virtual water flows between nations in relation to international crop trade A.Y. Hoekstra and P.Q. Hung - September 2002

12. Virtual water trade: Proceedings of the international expert meeting on virtual water trade

A.Y. Hoekstra (ed.) - February 2003

13. Virtual water flows between nations in relation to trade in livestock and livestock products

A.K. Chapagain and A.Y. Hoekstra - July 2003

14. The water needed to have the Dutch drink coffee

A.K. Chapagain and A.Y. Hoekstra - August 2003

15. The water needed to have the Dutch drink tea

A.K. Chapagain and A.Y. Hoekstra - August 2003

16. Water footprints of nations

Volume 1: Main Report, Volume 2: Appendices

A.K. Chapagain and A.Y. Hoekstra - November 2004

17. Saving water through global trade

A.K. Chapagain, A.Y. Hoekstra and H.H.G. Savenije - September 2005

18. The water footprint of cotton consumption

A.K. Chapagain, A.Y. Hoekstra, H.H.G. Savenije and R. Gautam - September 2005 



\section{Contents}

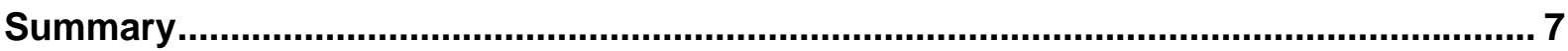

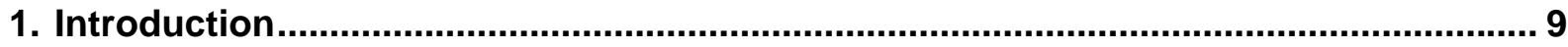

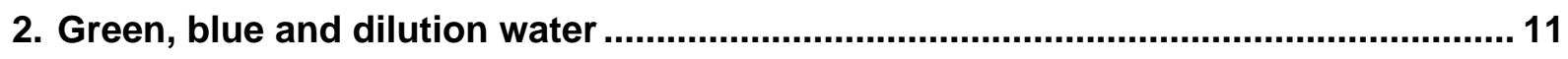

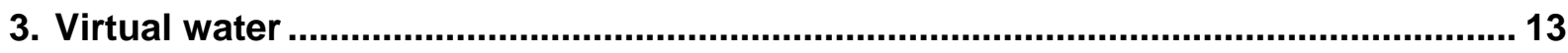

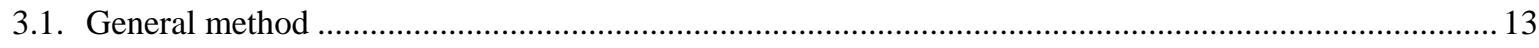

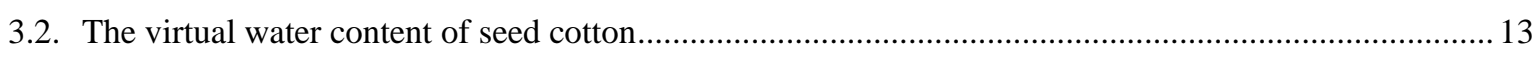

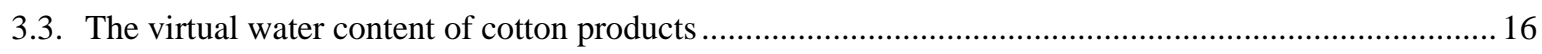

4. Impact on the water quality in the cotton producing countries ............................. 19

4.1. Impact due to use of fertilisers in crop production ............................................................................. 19

4.2. Impact due to use of chemicals in the processing stage.......................................................................... 20

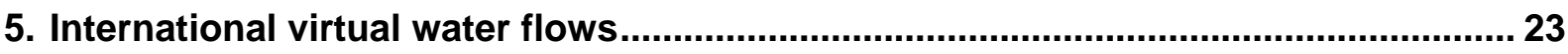

6. Water footprints related to consumption of cotton products .................................. 25

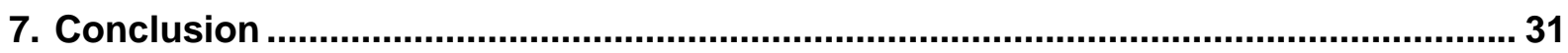

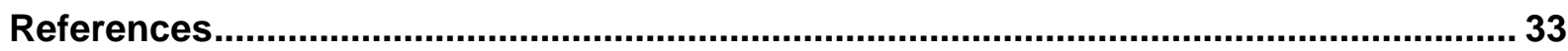





\section{Summary}

The consumption of a cotton product is connected to a chain of impacts on the water resources in the countries where cotton is grown and processed. The aim of this report is to assess the 'water footprint' of worldwide cotton consumption, identifying both the location and the character of the impacts. The study distinguishes between three types of impact: evaporation of infiltrated rainwater for cotton growth (green water use), withdrawal of ground- or surface water for irrigation or processing (blue water use) and water pollution during growth or processing. The latter impact is quantified in terms of the dilution volume necessary to assimilate the pollution. For the period 1997-2001 the study shows that the worldwide consumption of cotton products requires $256 \mathrm{Gm}^{3}$ of water per year, out of which about $42 \%$ is blue water, 39\% green water and $19 \%$ dilution water. Impacts are typically cross-border. About $84 \%$ of the water footprint of cotton consumption in the EU25 region is located outside Europe, with major impacts particularly in India and Uzbekistan. Given the general lack of proper water pricing mechanisms or other ways of transmitting production-information, cotton consumers have little incentive to take responsibility for the impacts on remote water systems. 



\section{Introduction}

Globally, freshwater resources are becoming scarcer due to an increase in population and subsequent increase in water appropriation and deterioration of water quality. The impact of consumption of people on the global water resources can be mapped with the concept of the 'water footprint', a concept introduced by Hoekstra and Hung (2002) and subsequently elaborated by Chapagain and Hoekstra (2004). The water footprint of a nation has been defined as the total volume of freshwater that is used to produce the goods and services consumed by the inhabitants of the nation. It deviates from earlier indicators of water use in the fact that the water footprint shows water demand related to consumption within a nation, while the earlier indicators (e.g. total water withdrawal for the various sectors of economy) show water demand in relation to production within a nation. The current report focuses on the assessment and analysis of the water footprints of nations insofar related to the consumption of cotton products. The period 1997-2001 has been taken as the period of analysis.

The water footprint concept is an analogue of the ecological footprint concept which was introduced in the 1990s (Rees, 1992; Wackernagel and Rees, 1996; Wackernagel et al., 1997; 1999). Whereas the ecological footprint denotes the area (hectares) needed to sustain a population, the water footprint represents the water volume (cubic metres per year) required.

Earlier water-footprint studies were limited to the quantification of resource use, i.e. the use of groundwater, surface water and soil water (Hoekstra and Hung, 2002; Chapagain and Hoekstra, 2003a; 2003b; 2004). The current study extends the water footprint concept through quantifying the impacts of pollution as well. This has been done by quantifying the dilution water volumes required to dilute waste flows to such extent that the quality of the water remains below agreed water quality standards. The rationale for including this water component in the definition of the water footprint is similar to the rationale for including the land area needed for uptake of anthropogenic carbon dioxide emissions in the definition of the ecological footprint. Land and water do not function as resource bases only, but as systems for waste assimilation as well. We realise that the method to translate the impacts of pollution into water requirements as applied in this study can potentially invoke a similar debate as is being held about the methods applied to translate the impacts of carbon dioxide emissions into land requirements (see e.g. Van den Bergh and Verbruggen, 1999; Van Kooten and Bulte, 2000). We would welcome such a debate, because of the societal need for proper natural resources accounting systems on the one hand and the difficulties in achieving the required scientific rigour in the accounting procedures on the other hand. The approach introduced in the current study should be seen as a first step; we will reflect in terms of possible improvements in the conclusions.

Some of the earlier studies on the impacts of cotton production were limited to the impacts in the industrial stage only (e.g. Ren, 2000), leaving out the impacts in the agricultural stage. Other cotton impact studies use the method of life cycle analysis and thus include all stages of production, but these studies are focussed on methodology rather than the quantification of the impacts (e.g. Proto et al., 2000; Seuring, 2004). Earlier studies that go in the direction of what we aim at in this report are the background studies for the cotton initiative of the World Wide Fund for Nature (Soth et al., 1999; De Man, 2001). In our study, however, we aim to synthesize the 
various impacts of cotton on water in one comprehensive indicator, the water footprint, and we introduce the spatial dimension by showing how water footprints of some nations particularly press in other parts of the world.

Cotton is the most important natural fibre used in the textile industries worldwide. Today, cotton takes up about 40 percent of textile production, while synthetic fibres take up about 55\% (Proto et al., 2000; Soth et al., 1999). During the period 1997-2001, international trade in cotton products constitutes 2 percent of the global merchandise trade value.

The impacts of cotton production on the environment are easily visible and have different faces. On the one hand there are the effects of water depletion, on the other hand the effects on water quality. In many of the major textile processing areas, downstream riparians can see from the river what was the latest colour applied in the upstream textile industry. The Aral Sea is the most famous example of the effects of water abstractions for irrigation. In the period 1960-2000, the Aral Sea in Central Asia lost approximately 60\% of its area and 80\% of its volume (Glantz 1998; Hall et al., 2001; Pereira et al., 2002; UNEP, 2002; Loh and Wackernagel, 2004) as a result of the annual abstractions of water from the Amu Darya and the Syr Darya - the rivers which feed the Aral Sea - to grow cotton in the desert.

About 53 percent of the global cotton field is irrigated, producing 73 percent of the global cotton production (Soth et al., 1999). Irrigated cotton is mainly grown in the Mediterranean and other warm climatic regions, where freshwater is already in short supply. Irrigated cotton is mainly located in dry regions: Egypt, Uzbekistan, and Pakistan. The province Xinjiang of China is entirely irrigated whereas in Pakistan and the North of India a major portion of the crop water requirements of cotton are met by supplementary irrigation. As a result, in Pakistan already 31 percent of all irrigation water is drawn from ground water and in China the extensive freshwater use has caused falling water tables (Soth et al., 1999). Nearly 70 percent of the world's cotton crop production is from China, USA, India, Pakistan and Uzbekistan (USDA, 2004). Most of the cotton productions rely on a furrow irrigation system. Sprinkler and drip systems are also adopted as an irrigated method in water scarce regions. However, hardly about 0.7 percent of land in the world is irrigated by this method (Postel, 1992). 


\section{Green, blue and dilution water}

From field to end product, cotton passes through a number of distinct production stages with different impacts on water resources. These stages of production are often carried out at different locations and consumption can take place at yet another place. For instance, Malaysia does not grow cotton, but imports raw cotton from China, India and Pakistan for processing in the textile industry and exports cotton clothes to the European market. For that reason the impacts of consumption of a final cotton product can only be found by tracing the origins of the product. The relation between the production stages and their impacts on the environment is shown in Figure 2.1 .

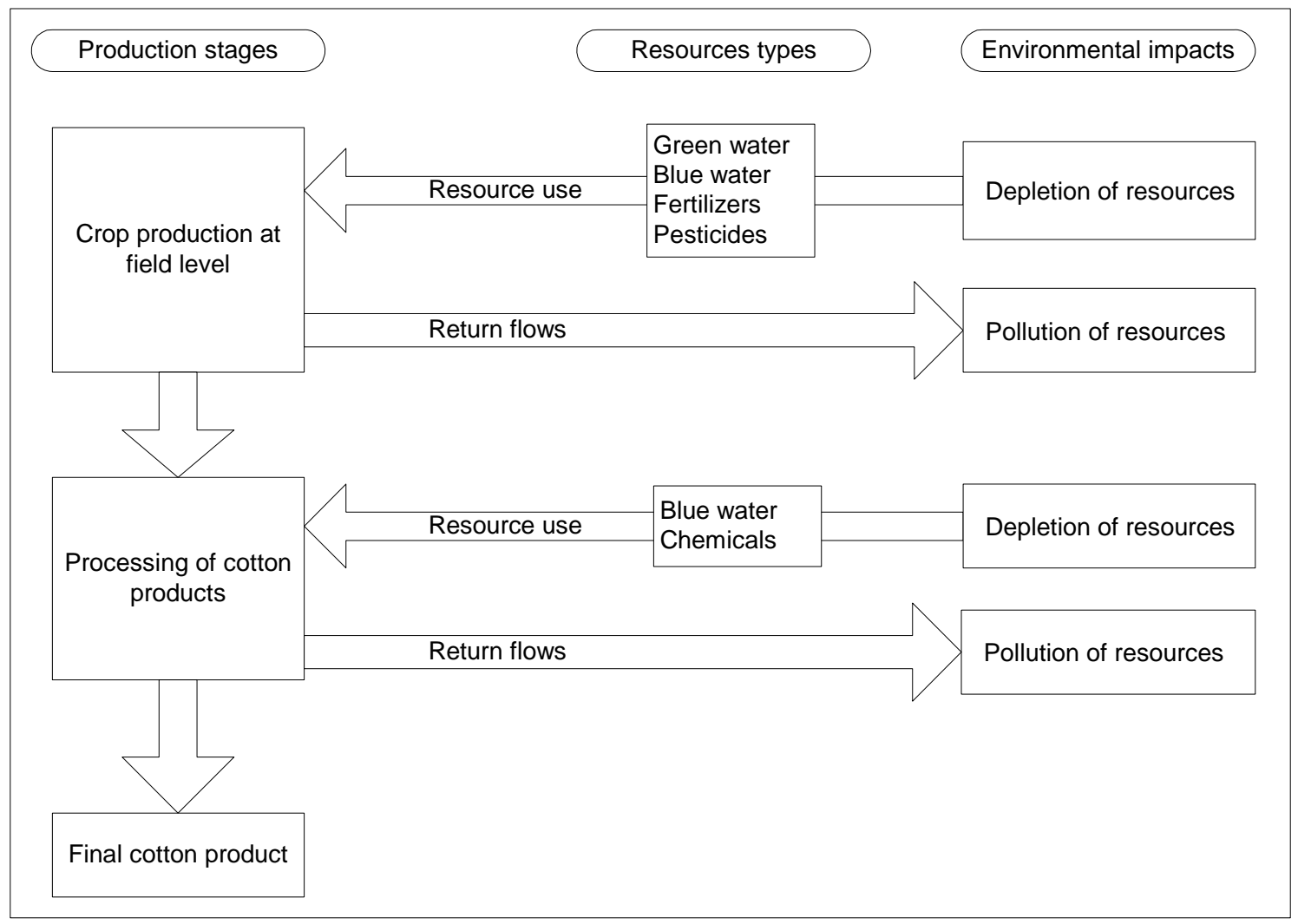

Figure 2.1. Impact of cotton production on the natural resources.

Although the chain from cotton growth to final product can take several distinct steps, there are two major stages: the agricultural stage (cotton production at field level) and the industrial stage (processing of seed cotton into final cotton products). In the first stage, there are three types of impact: evaporation of infiltrated rainwater for cotton growth, withdrawal of ground- or surface water for irrigation, and water pollution due to the leaching of fertilisers and pesticides. Following Falkenmark (1995), we use the term 'green water use' for the rainwater used for plant growth and 'blue water use' for the use of ground- and surface water for irrigation. Both green and blue water use can be quantified in terms of volumes used per year. The impact on water quality is quantified here and made comparable to the impacts of water use by translating the volumes of emitted chemicals into the dilution volume necessary to assimilate the pollution. In the industrial stage, there are two major impacts on water: abstraction of process water from surface or groundwater (blue water use), and pollution of water as a result of the waste flows from the cotton processing industries. The latter is again translated into a certain volume of dilution water requirement. 



\section{Virtual water}

\subsection{General method}

In order to assess the water footprint of cotton consumption in a country we need to know the use of domestic water resources for domestic cotton growth or processing and we need to know the water use associated with the import and export of raw cotton or cotton products. The total water footprint of a country includes two components: the part of the footprint that falls inside the country (internal water footprint) and the part of the footprint that presses on other countries in the world (external water footprint). The distinction refers to use of domestic water resources versus the use of foreign water resources (Chapagain and Hoekstra, 2004).

International trade of commodities brings along international flows of 'virtual water' (Hoekstra and Hung, 2005). 'Virtual water' is thereby defined as the volume of water used to produce a commodity (Allan, 1997; 1998). 'Virtual water' has also been called 'embedded water' and is a similar concept as 'embodied energy', which has been defined as the direct and indirect energy required to produce a good, service or entity (Herendeen, 2004). In accounting virtual water flows we keep track of which parts of these flows refer to green, blue and dilution water respectively.

\subsection{The virtual water content of seed cotton}

The virtual water content of seed cotton $\left(\mathrm{m}^{3} / \mathrm{ton}\right)$ has been calculated as the ratio of the volume of water $\left(\mathrm{m}^{3} / \mathrm{ha}\right)$ used during the entire period of crop growth to the corresponding crop yield (ton/ha). The volume of water used to grow crops in the field has two components: effective rainfall (green water) and irrigation water (blue water). The CROPWAT model (FAO, 2003a) has been used to estimate the effective rainfall and the irrigation requirements per country. The climate data have been taken from FAO (2003b; 2003c) for the most appropriate climatic stations (USDA/NOAA, 2005a) located in the major cotton producing regions of each country. The actual irrigation water use is taken equal to the irrigation requirements as estimated with the CROPWAT model for those countries where the whole harvesting area is reportedly irrigated. In the countries where only a certain fraction of the harvesting area is irrigated, the actual irrigation water use is taken equal to this fraction times the irrigation water requirements.

The 'green' virtual water content of the crop $\left(V_{g}\right)$ has been estimated as the ratio of the effective rainfall $\left(P_{e}\right)$ to the crop yield $(Y)$ (Equation 1). The 'blue' virtual water content of the crop $\left(V_{b}\right)$ has been taken equal to the ratio of the volume of irrigation water used $(I)$ to the crop yield $(Y)$ (Equation 2).

$$
\begin{aligned}
& V_{g}=\frac{P_{e}}{Y} \\
& V_{b}=\frac{I}{Y}
\end{aligned}
$$

The total virtual water content of seed cotton is the sum of the green and blue components, calculated separately for the fifteen largest cotton-producing countries. These countries contribute nearly $90 \%$ of the global cotton 
production (Table 3.1). For the remaining countries the global average virtual water content of seed cotton has been assumed. In the fifteen largest cotton-producing countries, the major cotton-producing regions have been identified (Table 3.2) so that the appropriate climate data could be selected. For regions with more than one climate station, the data for the relevant stations have been equally weighed assuming that the stations represent equally sized cotton-producing areas. National average crop water requirements have been calculated on the basis of the respective share of each region to the national production.

Table 3.1. The top-fifteen of seed cotton producing countries. Period 1997-2001.

\begin{tabular}{|c|c|c|c|c|}
\hline Countries & $\begin{array}{l}\text { Average production } \\
\text { (ton/yr)* }\end{array}$ & $\begin{array}{l}\text { \% contribution to global } \\
\text { production* }\end{array}$ & Planting period ${ }^{\star \star}$ & Yield (ton/ha)* \\
\hline China & $13,604,100$ & 25.0 & April/May & 3.16 \\
\hline USA & $9,699,662$ & 17.8 & March/May & 1.86 \\
\hline India & $5,544,380$ & 10.2 & April/May/July & 0.62 \\
\hline Pakistan & $5,159,839$ & 9.5 & May/June & 1.73 \\
\hline Uzbekistan & $3,342,380$ & 6.1 & April & 2.24 \\
\hline Turkey & $2,199,990$ & 4.0 & April/May & 3.12 \\
\hline Australia & $1,777,240$ & 3.3 & October/November & 3.74 \\
\hline Brazil & $1,613,193$ & 3.0 & October & 2.06 \\
\hline Greece & $1,253,288$ & 2.3 & April & 3.02 \\
\hline Syria & $1,016,594$ & 1.9 & April/May & 3.92 \\
\hline Turkmenistan & 954,440 & 1.8 & March/April & 1.72 \\
\hline Argentina & 712,417 & 1.3 & October/December & 1.16 \\
\hline Egypt & 710,259 & 1.3 & February/April & 2.39 \\
\hline Mali & 463,043 & 0.9 & May/July & 1.03 \\
\hline Mexico & 453,788 & 0.8 & April & 2.98 \\
\hline Others & $5,939,363$ & 10.9 & - & - \\
\hline World & $54,443,977$ & 100 & - & - \\
\hline
\end{tabular}

* Source: FAOSTAT (2004).

** Sources: UNCTAD (2005a); FAO (2005); Cotton Australia (2005).

Table 3.2. Main regions of cotton production within the major cotton producing countries.

\begin{tabular}{|c|c|}
\hline Country & Major cotton harvesting regions and their share to the national harvesting area* \\
\hline Argentina & Chaco (85\%) \\
\hline Australia & Queensland (23\%) and New Southwales (77\%) \\
\hline Brazil & $\begin{array}{l}\text { Parana (43\%), Sao Paulo (21\%), Bahia (8\%), Minas Gerais (5\%), Mato Grosso (5\%), Goias (4\%) and Mato } \\
\text { Gross do Sul (4\%) }\end{array}$ \\
\hline China & $\begin{array}{l}\text { Xinjiang (21.5\%), Henan (16.6\%), Jiangsu (11.5\%), Hubei }(11.4 \%) \text {, Shandong (10\%), Hebei (6.7\%), Anhui } \\
(6.4 \%) \text {, Hunan (5.2\%), Jiangxi (3.3\%), Sichuan (2.3\%), Shanxi }(1.7 \%) \text {, and Zhejiang (1.3\%) }\end{array}$ \\
\hline Egypt & Cairo $(85 \%)$ \\
\hline Greece & C. Macedonia (14\%), E. Macedonia (27\%), and Thessaly (51\%) \\
\hline India & $\begin{array}{l}\text { Punjab (18\%), Andhra Pradesh (14\%), Gujarat (14\%), Maharastha (13\%), Haryana (10\%), Madhya Pradesh } \\
(10 \%) \text {, Rajasthan (8\%), Karnataka (8\%), and Tamil Nadu (4\%) }\end{array}$ \\
\hline Mali & Segou (85\%) \\
\hline Mexico & Baja California, Chihuahua and Coahuila \\
\hline Pakistan & Sindh (15\%) and Punjab (85\%) \\
\hline Syria & Al Hasakah (33\%), Ar Raqqah (33\%) and Dayr az Zawr (33\%) \\
\hline Turkey & Aegean/Izmir (33.6\%), Antalya (1.2\%), Cukurova (20.2\%) and Southeasten Anotolia (45\%) \\
\hline Turkmenistan & Ahal $(85 \%)$ \\
\hline USA & $\begin{array}{l}\text { North Carolina (5.4\%), Missouri, Mississippi, W. Tennessee, E. Arkansas, Louisiana, Georgia (Macon) (27.7\%), } \\
\text { Georgia (Macon) (9.6\%), E. Texas (33.7\%) and California, Arizona (14.3\%) }\end{array}$ \\
\hline Uzbekistan & Fergana (85\%) \\
\hline
\end{tabular}

* Source: USDA/NOAA (2005b). 
The calculated national average crop water requirements for the fifteen largest cotton-producing countries are presented in Table 3.3. Total volumes of water use and the average virtual water content of seed cotton for the major cotton-producing countries are presented in Table 3.4. The global average virtual water content of seed cotton is $3644 \mathrm{~m}^{3} /$ ton. The global volume of water use for cotton crop production is $198 \mathrm{Gm}^{3} / \mathrm{yr}$ with nearly an equal share of green and blue water.

Table 3.3. Consumptive water use at field level for cotton production in the major cotton producing countries.

\begin{tabular}{|c|c|c|c|c|c|c|c|}
\hline & \multirow{2}{*}{$\begin{array}{l}\text { Crop water } \\
\text { requirement } \\
(\mathrm{mm})\end{array}$} & \multirow{2}{*}{$\begin{array}{l}\text { Effective } \\
\text { rainfall } \\
(\mathrm{mm})\end{array}$} & \multirow{2}{*}{$\begin{array}{l}\text { Blue water } \\
\text { requirement } \\
(\mathrm{mm})\end{array}$} & \multirow{2}{*}{$\begin{array}{l}\text { Irrigated share } \\
\text { of area * } \\
(\%)\end{array}$} & \multicolumn{3}{|c|}{ Consumptive water use } \\
\hline & & & & & $\begin{array}{l}\text { Blue water } \\
\quad(\mathrm{mm})\end{array}$ & $\begin{array}{l}\text { Green water } \\
\quad(\mathrm{mm})\end{array}$ & $\begin{array}{l}\text { Total } \\
(\mathrm{mm})\end{array}$ \\
\hline Argentina & 877 & 615 & 263 & 100 & 263 & 615 & 877 \\
\hline Australia & 901 & 322 & 579 & 90 & 521 & 322 & 843 \\
\hline Brazil & 606 & 542 & 65 & 15 & 10 & 542 & 551 \\
\hline China & 718 & 397 & 320 & 75 & 240 & 397 & 638 \\
\hline Egypt & 1009 & 0 & 1009 & 100 & 1009 & 0 & 1009 \\
\hline Greece & 707 & 160 & 547 & 100 & 547 & 160 & 707 \\
\hline India & 810 & 405 & 405 & 33 & 134 & 405 & 538 \\
\hline Mali & 993 & 387 & 606 & 25 & 151 & 387 & 538 \\
\hline Mexico & 771 & 253 & 518 & 95 & 492 & 253 & 746 \\
\hline Pakistan & 850 & 182 & 668 & 100 & 668 & 182 & 850 \\
\hline Syria & 1309 & 34 & 1275 & 100 & 1275 & 34 & 1309 \\
\hline Turkey & 963 & 90 & 874 & 100 & 874 & 90 & 963 \\
\hline Turkmenistan & 1025 & 69 & 956 & 100 & 956 & 69 & 1025 \\
\hline USA & 516 & 311 & 205 & 52 & 107 & 311 & 419 \\
\hline Uzbekistan & 999 & 19 & 981 & 100 & 981 & 19 & 999 \\
\hline
\end{tabular}

* Sources: Gillham et al. (1995); FAO (1999); Cotton Australia (2005); CCI (2005); WWF (1999).

Table 3.4. Volume of water use and virtual water content of seed cotton. Period: 1997-2001.

\begin{tabular}{|c|c|c|c|c|c|c|c|c|}
\hline & & \multicolumn{3}{|c|}{$\begin{array}{c}\text { Volume of water use } \\
\left(\mathrm{Gm}^{3} / \mathrm{yr}\right)\end{array}$} & \multirow{2}{*}{$\begin{array}{c}\text { Seed cotton } \\
\text { production (ton/yr) }\end{array}$} & \multicolumn{3}{|c|}{$\begin{array}{l}\text { Virtual water content } \\
\left(\mathrm{m}^{3} / \text { ton }\right)\end{array}$} \\
\hline & & Blue & Green & Total & & Blue & Green & Total \\
\hline Argentina & & 1.6 & 3.8 & 5.5 & 712,417 & 2,307 & 5,394 & 7,700 \\
\hline Australia & & 2.5 & 1.5 & 4 & $1,777,240$ & 1,408 & 870 & 2,278 \\
\hline Brazil & & 0.1 & 4.2 & 4.2 & $1,613,193$ & 46 & 2,575 & 2,621 \\
\hline China & & 10.3 & 17.1 & 27.5 & $13,604,100$ & 760 & 1,258 & 2,018 \\
\hline Egypt & & 3 & 0 & 3 & 710,259 & 4,231 & 0 & 4,231 \\
\hline Greece & & 2.3 & 0.7 & 2.9 & $1,253,288$ & 1,808 & 530 & 2,338 \\
\hline India & & 11.9 & 36.1 & 48 & $5,544,380$ & 2,150 & 6,512 & 8,662 \\
\hline Mali & & 0.7 & 1.7 & 2.4 & 463,043 & 1,468 & 3,750 & 5,218 \\
\hline Mexico & & 0.8 & 0.4 & 1.1 & 453,788 & 1,655 & 852 & 2,508 \\
\hline Pakistan & & 19.9 & 5.4 & 25.4 & $5,159,839$ & 3,860 & 1,054 & 4,914 \\
\hline Syria & & 3.3 & 0.1 & 3.4 & $1,016,594$ & 3,252 & 88 & 3,339 \\
\hline Turkey & & 6.2 & 0.6 & 6.8 & $2,199,990$ & 2,812 & 288 & 3,100 \\
\hline Turkmenistan & & 5.3 & 0.4 & 5.7 & 954,440 & 5,602 & 407 & 6,010 \\
\hline USA & & 5.6 & 16.2 & 21.8 & $9,699,662$ & 576 & 1,673 & 2,249 \\
\hline \multirow[t]{3}{*}{ Uzbekistan } & & 14.6 & 0.3 & 14.9 & $3,342,380$ & 4,377 & 83 & 4,460 \\
\hline & Sub-total & 88.2 & 88.6 & 176.8 & $48,504,613$ & - & - & - \\
\hline & Average & - & - & - & - & 1,818 & 1,827 & 3,644 \\
\hline \multirow[t]{2}{*}{ Other countries } & & 10.8 & 10.8 & 21.6 & $5,939,363$ & - & - & - \\
\hline & World & 99.0 & 99.4 & 198.4 & $54,443,977$ & - & - & - \\
\hline
\end{tabular}


The water use for cotton production differs considerably over the countries. Climatic conditions for cotton production are least attractive in Syria, Egypt, Turkmenistan, Uzbekistan and Turkey because evaporative demand in all these countries is very high $(1000-1300 \mathrm{~mm})$ while effective rainfall is very low $(0-100 \mathrm{~mm})$. The shortage of rain in these countries has been solved by irrigating the full harvesting area. Resulting yields vary from world-average (Turkmenistan) to very high (Syria, Turkey). Climatic conditions for cotton production are most attractive in the USA and Brazil. Evaporative demand is low (500-600 mm), so that vast areas can suffice without irrigation. Yields are a bit above world-average. India and Mali take a particular position by producing cotton under high evaporative water demand (800-1000 mm), short-falling effective rainfall (400 mm), and partial irrigation only (between a quarter and a third of the harvesting area), resulting in relatively low overall yields.

The average virtual water content of seed cotton in the various countries gives a first rough indication of the relative impacts of the various production systems on water. Cotton from India, Argentina, Turkmenistan, Mali, Pakistan, Uzbekistan, and Egypt is most water-intensive. Cotton from China and the USA on the other hand is very water-extensive. Since blue water generally has a much larger opportunity cost than green water, it makes sense to particularly look at the blue virtual water content of cotton in the various countries. China and the USA then still show a positive picture in this comparative analysis. Also Brazil comes in a positive light now, due to the acceptable yields under largely rain-fed conditions. The blue virtual water content and thus the impact per unit of cotton production are highest in Turkmenistan, Uzbekistan, Egypt, and Pakistan, followed by Syria, Turkey, Argentina and India.

It is interesting to compare neighbouring countries such as Brazil-Argentina and India-Pakistan. Cotton from Brazil is preferable over cotton from Argentina from a water resources point of view because growth conditions are better in Brazil (smaller irrigation requirements) and even despite the fact that the cotton harvesting area in Argentina is fully irrigated (compared to 15\% in Brazil), the yields in Argentina are only half the yield in Brazil. Similarly, cotton from India is to be preferred over cotton from Pakistan - again from a water resources point of view only - because the effective rainfall in Pakistan's cotton harvesting area is low compared to that in India and the harvesting area in Pakistan is fully irrigated. Although India achieves very low cotton yields per hectare, the blue water requirements per ton of product are much lower in India compared to Pakistan.

\subsection{The virtual water content of cotton products}

The different processing steps that transform the cotton plant through various intermediate products to some final products are shown in Figure 3.1. The virtual water content of seed cotton is attributed to its products following the methodology as introduced and applied by Chapagain and Hoekstra (2004). That means that the virtual water content of each processed cotton product has been calculated based on the product fraction (ton of crop product obtained per ton of primary crop) and the value fraction (the market value of the crop product divided by the aggregated market value of all crop products derived from one primary crop). The product fractions have been taken from the commodity trees in FAO (2003d) and UNCTAD (2005b). The value fractions have been calculated based on the market prices of the various products. The global average market prices of the cotton products have been calculated from ITC (2004). In calculating the virtual water content of fabric, the 
process water requirements for bleaching, dying and printing have been added (30 $\mathrm{m}^{3}$ per ton for bleaching, 140 $\mathrm{m}^{3}$ per ton for dying and $190 \mathrm{~m}^{3}$ per ton for printing). In the step of finishing there is also additional water required (140 $\mathrm{m}^{3}$ per ton). The process water requirements have to be understood as rough average estimates, because the actual water requirements vary considerably among various techniques used (Ren, 2000).

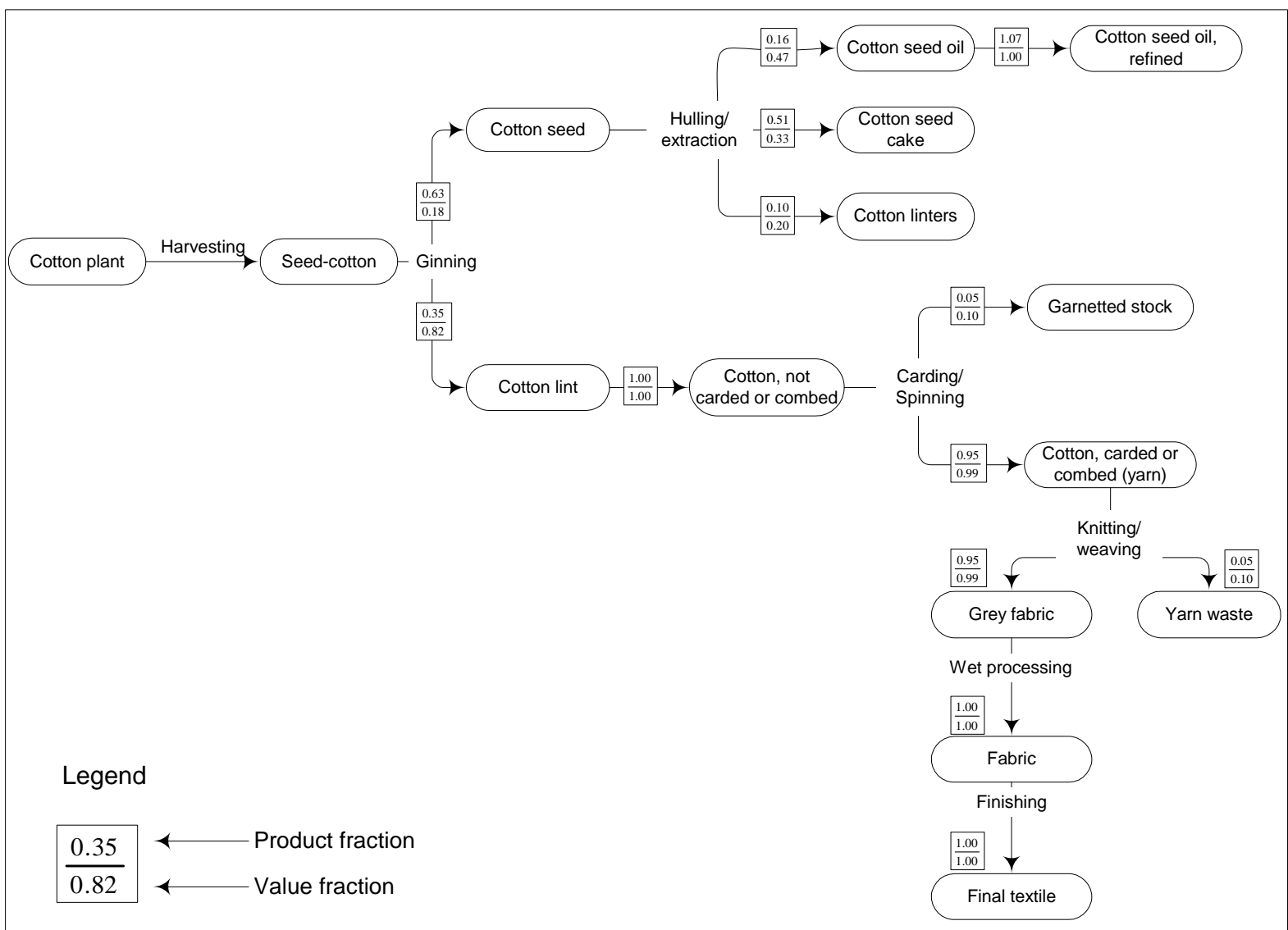

Figure 3.1. The product tree for cotton, showing the product fraction and value fraction per processing step.

The green and blue virtual water content of different cotton products for the major cotton producing countries is presented in Table 3.5. These water volumes do not yet include the volume of water necessary to dilute the fertiliser-enriched return flows from the cotton plantations and the polluted return flows from the processing industries. 
Table 3.5. Virtual water content of cotton products at different stages of production for the major cotton producing countries $\left(\mathrm{m}^{3} / \mathrm{ton}\right)$.

\begin{tabular}{|c|c|c|c|c|c|c|c|c|c|}
\hline & \multicolumn{2}{|c|}{ Cotton lint } & \multicolumn{2}{|c|}{ Grey fabric } & \multicolumn{2}{|c|}{ Fabric } & \multicolumn{3}{|c|}{ Final textile } \\
\hline & Blue & Green & Blue & Green & Blue & Green & Blue & Green & Total \\
\hline Argentina & 5,385 & 12,589 & 5,611 & 13,118 & 5,971 & 13,118 & 6,107 & 13,118 & 19225 \\
\hline Australia & 3,287 & 2,031 & 3,425 & 2,116 & 3,785 & 2,116 & 3,921 & 2,116 & 6037 \\
\hline Brazil & 107 & 6,010 & 112 & 6,263 & 472 & 6,263 & 608 & 6,263 & 6870 \\
\hline China & 1,775 & 2,935 & 1,849 & 3,059 & 2,209 & 3,059 & 2,345 & 3,059 & 5404 \\
\hline Egypt & 9,876 & 0 & 10,291 & 0 & 10,651 & 0 & 10,787 & 0 & 10787 \\
\hline Greece & 4,221 & 1,237 & 4,398 & 1,289 & 4,758 & 1,289 & 4,894 & 1,289 & 6183 \\
\hline India & 5,019 & 15,198 & 5,230 & 15,837 & 5,590 & 15,837 & 5,726 & 15,837 & 21563 \\
\hline Mali & 3,427 & 8,752 & 3,571 & 9,120 & 3,931 & 9,120 & 4,067 & 9,120 & 13188 \\
\hline Mexico & 3,863 & 1,990 & 4,026 & 2,073 & 4,386 & 2,073 & 4,522 & 2,073 & 6595 \\
\hline Pakistan & 9,009 & 2,460 & 9,388 & 2,563 & 9,748 & 2,563 & 9,884 & 2,563 & 12447 \\
\hline Syria & 7,590 & 204 & 7,909 & 213 & 8,269 & 213 & 8,405 & 213 & 8618 \\
\hline Turkey & 6,564 & 672 & 6,840 & 701 & 7,200 & 701 & 7,336 & 701 & 8037 \\
\hline Turkmenistan & 13,077 & 951 & 13,626 & 991 & 13,986 & 991 & 14,122 & 991 & 15112 \\
\hline USA & 1,345 & 3,906 & 1,401 & 4,070 & 1,761 & 4,070 & 1,897 & 4,070 & 5967 \\
\hline Uzbekistan & 10,215 & 195 & 10,644 & 203 & 11,004 & 203 & 11,140 & 203 & 11343 \\
\hline Global average & 4,242 & 4,264 & 4,421 & 4,443 & 4,781 & 4,443 & 4,917 & 4,443 & 9359 \\
\hline
\end{tabular}




\section{Impact on the water quality in the cotton producing countries}

\subsection{Impact due to use of fertilisers in crop production}

Cotton production affects water quality both in the stage of growing and the stage of processing. The impact in the first stage depends upon the amount of fertilizers used and the plant fertilizer uptake rate. The latter depends on the soil type, available quantity of fertilizer and stage of plant growth. The total quantity of pesticides used, in almost all cases, gets into either ground water or surface water bodies. Only 2.4 percent of the world's arable land is planted with cotton yet cotton accounts for 24 percent of the world's insecticide market and 11 percent of the sale of global pesticides (WWF, 2003). The nutrients (nitrogen, phosphorus, potash and other minor nutrients) and pesticides that leach out of the plant root zone can contaminate groundwater and surface water. The nitrite ions $\left(\mathrm{NO}_{2}^{-}\right)$in blood can inactivate haemoglobin, reducing the oxygen carrying capacity of the blood and the infants under 3 months are at risk. Nitrates in the drinking water can be harmful as the nitrite ions are formed in the gastrointestinal tract by the chemical reduction of the nitrate ions. Hence the target of the regulation is the nitrate intake. In surface waters, fertilizers can stimulate growth of algae and other aquatic plants, which results in a reduction of dissolved oxygen in the water when dead plant material decomposes (a process known as eutrophication).

Phosphorus has low mobility in the soil and leaching is generally not a problem. Phosphates can react with other minerals in the soil forming insoluble compounds and the amount of potassium leached is influenced by the cation exchange capacity of the soil. Instead, mobility to the roots is the prime limitation to uptake. Potassium mobility in soils is intermediate between nitrogen and phosphorus, but is not easily leached because it has a positive charge $(\mathrm{K}+)$ which causes it to be attracted to negatively charged soil colloids.

The main nitrogen processes in the soil are immobilisation/mineralization from organic matter, adsorption/desorption form cation-anion exchange sites on clay and organic matter and the application from external sources. The nitrogen is lost in various forms such as seed cotton, de-nitrification, leaching, volatilisation and burning stubble. Nitrogen is most susceptible to leaching because it cannot be retained by the soil. The nitrate ion, $\mathrm{NO}_{3}{ }^{-}$is not strongly held to clay and organic matter and is subject to movement within the soil profile. Downward movement of ions (leaching) is a problem in coarse-textured soils (loams and sands). In clay soils where movement of soil water is slow, nitrate movement is also slow. Greater losses occur from poorly structured or poorly drained soils compared to well-structured and well drained soils. The loss of fertilizer $\mathrm{N}$ during crop growth is variable and site dependent. Deep drainage and nutrient leaching are significant under irrigated cotton. During flood irrigation, surface soil high in nitrate is washed into cracks with the irrigation.

About 60 percent of the total nitrogen applied is removed in the seed cotton (CRC, 2004). Silvertooth et al. (2001) approximated that out of the total nitrogen applied to 80 percent of it gets recovered in the cotton field. The residual fraction either goes to the atmosphere by de-nitrification or discharges to the free flowing water bodies. In the present study, the quantity of $\mathrm{N}$ that reaches free flowing water bodies is assumed to be 10 percent 
of the applied rate assuming a steady state balance at root zone in the long run. The effect of use of pesticides and herbicides in cotton farming to the environment has not been analysed.

The total volume of water required per ton $\mathrm{N}$ is calculated considering the volume of nitrogen leached (ton/ton) and the permissible limit (ton $/ \mathrm{m}^{3}$ ) in the free flowing surface water bodies. The standard recommended by EPA (2005) for nitrate in drinking water is 10 milligrams per litre (measured as nitrogen) and has been taken to calculate the necessary dilution water volume. This is a conservative approach, since natural background concentration of $\mathrm{N}$ in the water used for dilution has been assumed negligible.

We have used the average rate of fertiliser application for the year 1998 as reported by IFA et al. (2002). The total volume of fertilizer applied is calculated based on the average area of cotton harvesting for the concerned period (Table 4.1).

Table 4.1. Fertilizer application and the volume of water required to dilute the fertilizers leached to the water bodies. Period: 1997-2001.

\begin{tabular}{|c|c|c|c|c|c|c|c|c|c|}
\hline \multirow[t]{2}{*}{ Countries } & \multicolumn{3}{|c|}{$\begin{array}{l}\text { Average fertilizer } \\
\text { application rate* } \\
(\mathrm{kg} / \mathrm{ha})\end{array}$} & \multicolumn{3}{|c|}{$\begin{array}{l}\text { Total fertilizer applied } \\
\text { (ton/yr) }\end{array}$} & \multirow{2}{*}{$\begin{array}{r}\text { Nitrogen } \\
\text { leached to the } \\
\text { water bodies } \\
\text { (ton/yr) }\end{array}$} & \multicolumn{2}{|c|}{$\begin{array}{l}\text { Volume of dilution } \\
\text { water required }\end{array}$} \\
\hline & $\mathrm{N}$ & $\mathrm{P}_{2} \mathrm{O}_{5}$ & $\mathrm{~K}_{2} \mathrm{O}$ & $\mathrm{N}$ & $\mathrm{P}_{2} \mathrm{O}_{5}$ & $\mathrm{~K}_{2} \mathrm{O}$ & & $\left(10^{6} \mathrm{~m}^{3} / \mathrm{yr}\right)$ & $\left(\mathrm{m}^{3} /\right.$ ton $)$ \\
\hline Argentina & 40 & 5 & & 25,009 & 3,126 & & 2,501 & 157 & 351 \\
\hline Australia & 121 & 20 & 12.4 & 58,087 & 9,601 & 5,953 & 5,809 & 581 & 327 \\
\hline Brazil & 40 & 50 & 50 & 30,674 & 38,342 & 38,342 & 3,067 & 307 & 190 \\
\hline China & 120 & 70 & 25 & 516,637 & 301,372 & 107,633 & 51,664 & 5,166 & 380 \\
\hline Egypt & 54 & 57 & 57 & 16,076 & 16,969 & 16,969 & 1,608 & 1,175 & 226 \\
\hline Greece & 127 & 39 & 3.5 & 52,630 & 16,162 & 1,450 & 5,263 & 526 & 420 \\
\hline India & 66 & 28 & 6 & 588,675 & 249,741 & 53,516 & 58,868 & 5,887 & 1,062 \\
\hline Mali & 35 & & & 15,710 & & & 1,571 & 161 & 339 \\
\hline Mexico & 120 & 30 & & 18,315 & 4,579 & & 1,831 & 183 & 404 \\
\hline Pakistan & 180 & 28 & 0.4 & 536,720 & 83,490 & 1,193 & 53,672 & 5,367 & 1,040 \\
\hline Syria & 50 & 50 & & 12,964 & 12,964 & & 1,296 & 130 & 128 \\
\hline Turkey & 127 & 39 & 3.5 & 89,927 & 27,615 & 2,478 & 8,993 & 899 & 409 \\
\hline Turkmenistan & 210 & 45 & 1.2 & 117,495 & 25,178 & 671 & 11,750 & 250 & 1,231 \\
\hline USA & 120 & 60 & 85 & 625,544 & 312,772 & 443,094 & 62,554 & 6,255 & 645 \\
\hline Uzbekistan & 210 & 45 & 1.2 & 313,274 & 67,130 & 1,790 & 31,327 & 3,133 & 937 \\
\hline Average** & 91 & 35 & 20 & & & & & & 622 \\
\hline Sum & & & & $3,017,737$ & $1,169,041$ & 673,090 & 301,774 & 30,177 & \\
\hline
\end{tabular}

* Source: IFA et al. (2002). For Uzbekistan, Mali and Turkey, the fertiliser application rate has been taken from Turkmenistan, Nigeria and Greece respectively.

**The global average fertilizer application rate has been calculated from the country-specific rates, weighted on the basis of the share of a country in the global area of cotton production.

\subsection{Impact due to use of chemicals in the processing stage}

The average volumes of water use in wet processing (bleaching, dying and printing) and finishing stage are 360 $\mathrm{m}^{3} /$ ton and $136 \mathrm{~m}^{3} /$ ton of cotton textile respectively (USEPA, 1996). The biological oxygen demand (BOD), chemical oxygen demand (COD), total suspended solids (TSS) and the total dissolved solids (TDS) in the effluent from a typical textile industry are given by UNEP IE (1996) and presented in Table 4.2. In this study, the maximum permissible limits for effluents to discharge into surface and ground water bodies are taken from the guidelines set by the World Bank (1999). 
Table 4.2. Waste water characteristics at different stages of processing cotton textiles and permissible limits to discharge into water bodies.

\begin{tabular}{|c|c|c|c|c|c|}
\hline \multirow{2}{*}{ Process } & \multirow{2}{*}{$\begin{array}{l}\text { Waste water } \\
\text { volume*} \\
\left(\mathrm{m}^{3} / \text { ton }\right)\end{array}$} & \multicolumn{4}{|c|}{$\begin{array}{c}\text { Pollutants** } \\
\text { (kg per ton of textile product) }\end{array}$} \\
\hline & & BOD & COD & TSS & TDS \\
\hline Wet processing & 360 & 32 & 123 & 25 & 243 \\
\hline Bleaching & 30 & 5 & 13 & & 28 \\
\hline Dying & 142 & 6 & 24 & & 180 \\
\hline Printing & 188 & 21 & 86 & 25 & 35 \\
\hline Finishing & 136 & 6 & 25 & 12 & 17 \\
\hline Total & 496 & 38 & 148 & 37 & 260 \\
\hline Permissible limits (mi & & 50 & 250 & 50 & \\
\hline
\end{tabular}

* Source: USEPA (1996)

** Source: UNEP IE (1996)

*** Source: WB (1999)

As the maximum limits for different pollutants are different, the volume of water required to meet the desired level of dilution will be different per pollutant category in each production stage. Per production stage, the pollutant category that requires most dilution water has been taken as indicative for the total dilution water requirement (Table 4.3). The virtual water content of a few specific consumer products is shown in Table 4.4.

Table 4.3. Volume of water necessary to dilute pollution per production stage.

\begin{tabular}{|c|c|c|c|c|}
\hline \multirow[t]{2}{*}{ Stage of production } & \multicolumn{3}{|c|}{$\begin{array}{l}\text { Volume of water per pollutant category } \\
\left(\mathrm{m}^{3} / \text { ton of cotton textile }\right)\end{array}$} & \multirow{2}{*}{ 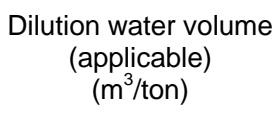 } \\
\hline & BOD & COD & TSS & \\
\hline Wet processing & 640 & 492 & 500 & 640 \\
\hline Finishing & 120 & 100 & 240 & 240 \\
\hline $\begin{array}{l}\text { Wet processing and finishing carried at the } \\
\text { same place }\end{array}$ & 760 & 592 & 740 & 760 \\
\hline $\begin{array}{l}\text { Wet processing and finishing carried at } \\
\text { different place }\end{array}$ & - & - & - & 880 \\
\hline
\end{tabular}

Table 4.4. Global average virtual water content of some selected consumer products.

\begin{tabular}{|c|c|c|c|c|c|}
\hline & \multirow{2}{*}{$\begin{array}{l}\text { Standard } \\
\text { weight } \\
\text { (gram) }\end{array}$} & \multicolumn{4}{|c|}{$\begin{array}{l}\text { Virtual water content } \\
\text { (litres) }\end{array}$} \\
\hline & & Blue water & Green water & Dilution water & Total volume of water \\
\hline 1 pair of Jeans & 1,000 & 4,900 & 4,450 & 1,500 & 10,850 \\
\hline 1 Single bed sheets & 900 & 4,400 & 4,000 & 1,350 & 9,750 \\
\hline 1 T-shirt & 250 & 1,230 & 1,110 & 380 & 2,720 \\
\hline 1 Diaper & 75 & 370 & 330 & 110 & 810 \\
\hline 1 Johnson's cotton bud & 0.333 & 1.6 & 1.5 & 0.5 & 3.6 \\
\hline
\end{tabular}





\section{International virtual water flows}

Virtual water flows between nations have been calculated by multiplying commodity trade flows by their associated total virtual water content:

$$
F\left[n_{e}, n_{i}, c\right]=T\left[n_{e}, n_{i}, c\right] \times V_{t}\left[n_{e}, c\right]
$$

in which $F$ denotes the virtual water flow $\left(\mathrm{m}^{3} / \mathrm{yr}\right)$ from exporting country $n_{e}$ to importing country $n_{i}$ as a result of trade in cotton product $c$; $T$ the commodity trade (ton/yr) from the exporting to the importing country; and $V_{t}$ the total virtual water content $\left(\mathrm{m}^{3} / \mathrm{ton}\right)$ of the commodity in the exporting country. We have taken into account the international trade of cotton products for the complete set of countries from the Personal Computer Trade Analysis System of the International Trade Centre, produced in collaboration with UNCTAD/WTO. It covers trade data from 146 reporting countries disaggregated by product and partner countries for the period 1997-2001 (ITC, 2004).

For the calculation of international virtual water flows, all cotton products are considered as reported in the database of ITC (2004). It includes the complete set of cotton products from the commodity groups 12, 14, 15, 23, 60, 61, 62 and 63. From group 52, only those products with more than 85 percent of cotton in their composition are considered.

The calculated virtual water flows between countries in relation to the international trade in cotton products add up to $204 \mathrm{Gm}^{3} / \mathrm{yr}$ at a global scale (an average for the period 1997-2001). About $43 \%$ of this total flow refers to blue water, about $40 \%$ to green water and about $17 \%$ to dilution water (Tables 5.1 and 5.2). The virtual water flows in relation to international trade in all crop, livestock and industrial products add up to $1625 \mathrm{Gm}^{3} / \mathrm{yr}^{\text {at a }}$ global scale (Chapagain and Hoekstra, 2004). The global sum of annual gross virtual water flows between nations related to cotton trade is thus 12 per cent of the total sum of international virtual water flows.

Table 5.1. Gross virtual water export from the major cotton producing countries related to export of cotton products. Period: 1997-2001.

\begin{tabular}{|c|c|c|c|c|c|}
\hline & $\begin{array}{c}\text { Green water } \\
\left(\mathrm{Gm}^{3} / \mathrm{yr}\right)\end{array}$ & $\begin{array}{c}\text { Blue water } \\
\left(\mathrm{Gm} \mathrm{m}^{3} / \mathrm{yr}\right)\end{array}$ & $\begin{array}{c}\text { Dilution water } \\
\left(\mathrm{Gm}^{3} / \mathrm{yr}\right)\end{array}$ & $\begin{array}{c}\text { Total } \\
\left(\mathrm{Gm}^{3} / \mathrm{yr}\right)\end{array}$ & $\begin{array}{l}\text { Contribution to the } \\
\text { global flows }\end{array}$ \\
\hline Argentina & 1.98 & 0.85 & 0.13 & 2.95 & $1 \%$ \\
\hline Australia & 1.44 & 2.34 & 0.55 & 4.34 & $2 \%$ \\
\hline Brazil & 1.03 & 0.07 & 0.17 & 1.27 & $1 \%$ \\
\hline China & 11.36 & 9.32 & 5.43 & 26.11 & $13 \%$ \\
\hline Egypt & - & 1.72 & 0.13 & 1.85 & $1 \%$ \\
\hline Greece & 0.41 & 1.41 & 0.36 & 2.18 & $1 \%$ \\
\hline India & 16.83 & 5.75 & 3.08 & 25.66 & $13 \%$ \\
\hline Mali & 1.17 & 0.46 & 0.11 & 1.73 & $1 \%$ \\
\hline Mexico & 1.04 & 2.23 & 0.86 & 4.13 & $2 \%$ \\
\hline Pakistan & 2.87 & 10.64 & 3.05 & 16.56 & $8 \%$ \\
\hline Syria & 0.04 & 1.63 & 0.07 & 1.75 & $1 \%$ \\
\hline Turkey & 0.40 & 4.08 & 0.89 & 5.37 & $3 \%$ \\
\hline Turkmenistan & 0.10 & 1.41 & 0.31 & 1.83 & $1 \%$ \\
\hline Uzbekistan & 0.15 & 7.74 & 1.66 & 9.55 & $5 \%$ \\
\hline USA & 11.18 & 4.34 & 5.18 & 20.70 & $10 \%$ \\
\hline Others & 31.06 & 32.73 & 13.83 & 77.62 & $38 \%$ \\
\hline Global flows & 81.05 & 86.72 & 35.83 & 203.6 & \\
\hline
\end{tabular}


The countries producing more than 90 percent of seed cotton are responsible for only 62 percent of the global virtual water exports (Table 5.1). This can be understood from the fact that the countries that import the raw cotton from the major producing countries export significant volumes again to other countries, often in some processed form. Export of cotton products made from imported raw cotton is significant for instance in Japan, the European Union, and Canada.

Table 5.2. Largest gross virtual water importers $\left(\mathrm{Gm}^{3} / \mathrm{yr}\right)$ related to the international trade of cotton products. Period: $1997-2001$.

\begin{tabular}{|c|c|c|c|c|c|}
\hline & $\begin{array}{c}\text { Green water } \\
\left(\mathrm{Gm}^{3} / \mathrm{yr}\right)\end{array}$ & $\begin{array}{c}\text { Blue water } \\
\left(\mathrm{Gm}^{3} / \mathrm{yr}\right)\end{array}$ & $\begin{array}{c}\text { Dilution water } \\
\left(\mathrm{Gm}^{3} / \mathrm{yr}\right)\end{array}$ & $\begin{array}{c}\text { Total } \\
\left(\mathrm{Gm}^{3} / \mathrm{yr}\right)\end{array}$ & $\begin{array}{l}\text { Contribution to the } \\
\text { global flows }\end{array}$ \\
\hline Brazil & 2 & 1.5 & 0.4 & 3.9 & $2 \%$ \\
\hline Canada & 1.6 & 1 & 0.6 & 3.2 & $2 \%$ \\
\hline China & 15.6 & 15.9 & 6.7 & 38.2 & $19 \%$ \\
\hline France & 2.4 & 3.2 & 1.2 & 6.8 & $3 \%$ \\
\hline Germany & 3.5 & 5 & 1.8 & 10.4 & $5 \%$ \\
\hline Indonesia & 1.9 & 2 & 0.7 & 4.6 & $2 \%$ \\
\hline Italy & 2.9 & 4.5 & 1.3 & 8.7 & $4 \%$ \\
\hline Japan & 3.3 & 3.3 & 1.5 & 8.2 & $4 \%$ \\
\hline Korea Rep. & 2.6 & 2.8 & 1 & 6.4 & $3 \%$ \\
\hline Mexico & 6.4 & 2.9 & 3.2 & 12.5 & $6 \%$ \\
\hline Netherlands & 1.4 & 1.6 & 0.7 & 3.7 & $2 \%$ \\
\hline Russian federation & 0.5 & 2.5 & 0.6 & 3.7 & $2 \%$ \\
\hline Thailand & 1.5 & 1.4 & 0.5 & 3.3 & $2 \%$ \\
\hline Turkey & 1.4 & 2.6 & 0.7 & 4.7 & $2 \%$ \\
\hline UK & 2.9 & 3.1 & 1.3 & 7.3 & $4 \%$ \\
\hline USA & 10 & 12.2 & 5.3 & 27.5 & $14 \%$ \\
\hline Others & 21.2 & 21.1 & 8.3 & 50.6 & $25 \%$ \\
\hline Global flows & 81.05 & 86.72 & 35.83 & 203.6 & \\
\hline
\end{tabular}

Pakistan, China, Uzbekistan and India are the largest exporters of blue water. These countries export a lot of water in absolute sense, but in relative sense as well: more than half of the blue water used for cotton irrigation enters export products. The USA also appears in the top-list of total virtual water exporters due to its large share of green water export. The largest gross dilution volume exporters are China, USA and Pakistan, implying that the international trade in cotton products are having larger impact on the water quality in these countries. 


\section{Water footprints related to consumption of cotton products}

In assessing a national water footprint due to domestic cotton consumption we distinguish between the internal and the external footprint. The internal water footprint is defined as the use of domestic water resources to produce cotton products consumed by inhabitants of the country. It is the sum of the total volume of water used from the domestic water resources to produce cotton products minus the total volume of virtual water export related to export of domestically produced cotton products. The external water footprint of a country is defined as the annual volume of water resources used in other countries to produce cotton products consumed by the inhabitants of the country concerned. The external water footprint is calculated by taking the total virtual water import into the country and subtracting the volume of virtual water exported to other countries as a result of reexport of imported products.

The global water footprint related to the consumption of cotton products is estimated at $256 \mathrm{Gm}^{3} / \mathrm{yr}$, which is 43 $\mathrm{m}^{3} / \mathrm{yr}$ per capita in average. About $42 \%$ of this footprint is due to the use of blue water, another $39 \%$ to the use of green water and about $19 \%$ to the dilution water requirements (Table 6.1 ). About $44 \%$ of the global water use for cotton growth and processing is not for serving the domestic market but for export. If we do not consider the water requirements for cotton products only, but take into account the water needs for the full scope of consumed goods and services, the global water footprint is $7450 \times 10^{9} \mathrm{~m}^{3} / \mathrm{yr}$ (Chapagain and Hoekstra, 2004). This includes the use of green and blue water for the full spectrum of the global consumption goods and services, but it excludes the water requirement for dilution of waste flows. As a proxy for the latter we take here the rough estimate provided by Postel et al. (1996), who estimate the global dilution water requirement at $2350 \times 10^{9} \mathrm{~m}^{3} / \mathrm{yr}$. This means that the full global water footprint is about $9800 \times 10^{9} \mathrm{~m}^{3} / \mathrm{yr}$. The global water footprint related to cotton consumption is $256 \times 10^{9} \mathrm{~m}^{3} / \mathrm{yr}$, which means that the consumption of cotton products takes a share of 2.6 per cent of the full global water footprint.

Table 6.1. The global water footprint due to cotton consumption (Gm3/yr). Period: 1997-2001.

\begin{tabular}{|c|c|c|c|c|c|}
\hline & $\begin{array}{l}\text { Blue water } \\
\text { footprint }\end{array}$ & $\begin{array}{l}\text { Green water } \\
\text { footprint }\end{array}$ & $\begin{array}{l}\text { Dilution water } \\
\text { footprint }\end{array}$ & $\begin{array}{l}\text { Total water } \\
\text { footprint }\end{array}$ & $\begin{array}{c}\text { Contribution to } \\
\text { the total water } \\
\text { footprint }\end{array}$ \\
\hline Internal water footprint* & 59.6 & 54.8 & 28.5 & 143 & $56 \%$ \\
\hline External water footprint* & 48.0 & 44.7 & 20.7 & 113 & $44 \%$ \\
\hline Total water footprint & 108 & 99 & 49 & 256 & \\
\hline $\begin{array}{l}\text { Contribution to the total water } \\
\text { footprint }\end{array}$ & $42 \%$ & $39 \%$ & $19 \%$ & & \\
\hline
\end{tabular}

* The internal water footprint at global scale refers to the aggregated internal water footprints of all nations of the world. The external water footprint refers here to the aggregated external water footprints of all nations

The countries with the largest impact on the foreign water resources are China, USA, Mexico, Germany, UK, France, and Japan (Appendix I). About half of China's water footprint due to cotton consumption is within China (the internal water footprint); the other half (the external footprint) presses in other countries, mainly in India (dominantly green water use) and Pakistan (dominantly blue water use). 
Per country, the water footprint as a result of domestic cotton consumption can be mapped as has been done for the USA in Figure 6.1. The arrows show the tele-connections between the area of consumption (the USA) and the areas of impact (notably India, Pakistan, China, Mexico and Dominican Republic). The total water footprint of an average US citizen due to the consumption of cotton products is $135 \mathrm{~m}^{3} / \mathrm{yr}$ - more than three times the global average - out of which about half is from the use of external water resources. If all world citizens would consume cotton products at the US rate, other factors remaining equal, the global water use would increase by five per cent [from 9800 to $10300 \mathrm{Gm}^{3} / \mathrm{yr}$ ], which is quite substantial given that humanity already uses more than half of the runoff water that is reasonably accessible (Postel et al., 1996).

For proper understanding of the impact map shown in Figure 6.1, it should be observed here that the map shows the full internal water footprint of the USA plus the external water footprints in other countries insofar easily traceable. For instance, USA imports several types of cotton products from the EU, that together contain 430 million $\mathrm{m}^{3} / \mathrm{yr}$ of virtual water, but these cotton products do not fully originate from the EU25. In fact, the EU25 imports raw cotton, grey fabrics and final products from countries such as India, Uzbekistan and Pakistan, then partly or fully processes these products into final products and ultimately exports to the USA. Out of the 430 million $\mathrm{m}^{3} / \mathrm{yr}$ of virtual water exported from the EU25 to the USA, only $16 \%$ is actually water appropriated within the EU25; the other 84\% refers to water use in countries from which the EU25 imports (e.g. India, Uzbekistan, Pakistan). For simplicity, we show in the map only the 'direct' external footprints (tracing the origin of imported products only one step back), and not the 'indirect' external footprints. Adding the latter would mean adding for instance an arrow from India to EU25, which then is forwarded to the USA. Doing so for all indirect external water footprints would create an incomprehensible map. For the same reason, we have shown only arrows for the largest virtual water flows towards the USA.

The water footprint as a result of cotton consumption in Japan is mapped in Figure 6.2. For their cotton the Japanese consumers most importantly rely on the water resources of China, Pakistan, India, Australia and the USA. Japan does not grow cotton, and also does not have a large cotton processing industry. The Japanese water footprint due to consumption of cotton products is $4.6 \mathrm{Gm}^{3} / \mathrm{yr}$, of which 95 percent presses in other countries. The cotton products imported from Pakistan put a large pressure on Pakistan's scarce blue water resources. In China and even more so in India, cotton is produced with lower inputs of blue water (in relation to the green water inputs), so that cotton products from China and India put less stress per unit of cotton product on the scarce blue water resources than in Pakistan.

Figure 6.3 shows the water footprint due to cotton consumption in the twenty-five countries of the European Union (EU25). 84\% of EU's cotton-related water footprint lies outside the EU. From the map it can be seen that, for their cotton supply, the European community most heavily depends on the water resources of India. This puts stress on the water availability for other purposes in India. In India one third of the cotton harvest area is being irrigated; particularly cotton imports from these irrigated areas have a large opportunity cost, because the competition for blue water resources is higher than for the green water resources. If we look at the impacts of European cotton consumption on blue water resources, the impacts are even higher in Uzbekistan than in India. Uzbekistan uses $14.6 \mathrm{Gm}^{3} / \mathrm{yr}$ of blue water to irrigate cotton fields, out of which it exports $3.0 \mathrm{Gm}^{3} / \mathrm{yr}$ in virtual 
form to the EU25. The consumers in the EU25 countries thus indirectly (and mostly unconsciously) contribute for about 20 per cent to the desiccation of the Aral Sea. In terms of pollution, cotton consumption in the EU25 has largest impacts in India, Uzbekistan, Pakistan, Turkey and China. These impacts are partly due to the use of fertiliser in the cotton fields and partly to the use of chemicals in the cotton processing industries. Cotton consumption in the EU25 also causes pollution in the region itself, mainly from the processing of imported raw cotton or grey fabrics into final products.

The three components of a water footprint - green water use, blue water use and dilution water requirement affect water systems in different ways. Use of blue water generally affects the environment more than green water use. Blue water is lost to the atmosphere where otherwise it would have stayed in the ground or river system where it was taken from. Green water on the other hand would have been evaporated through another crop or through natural vegetation if it would not have been used for cotton growth. Therefore there should generally be more concern with the 'blue water footprint' than with the 'green water footprint'. The part of the water footprint that refers to dilution water requirements deserves attention as well, since pollution is a choice and not necessary. Waste flows from cotton industries can be treated so that no dilution water would be required at all. An alternative to treatment of waste flows is reduction of waste flows. With cleaner production technology, the use of chemicals in cotton industries can be reduced by 30 per cent, with a reduction of the COD content in the effluent of 60 percent (Visvanathan et al., 2000). 


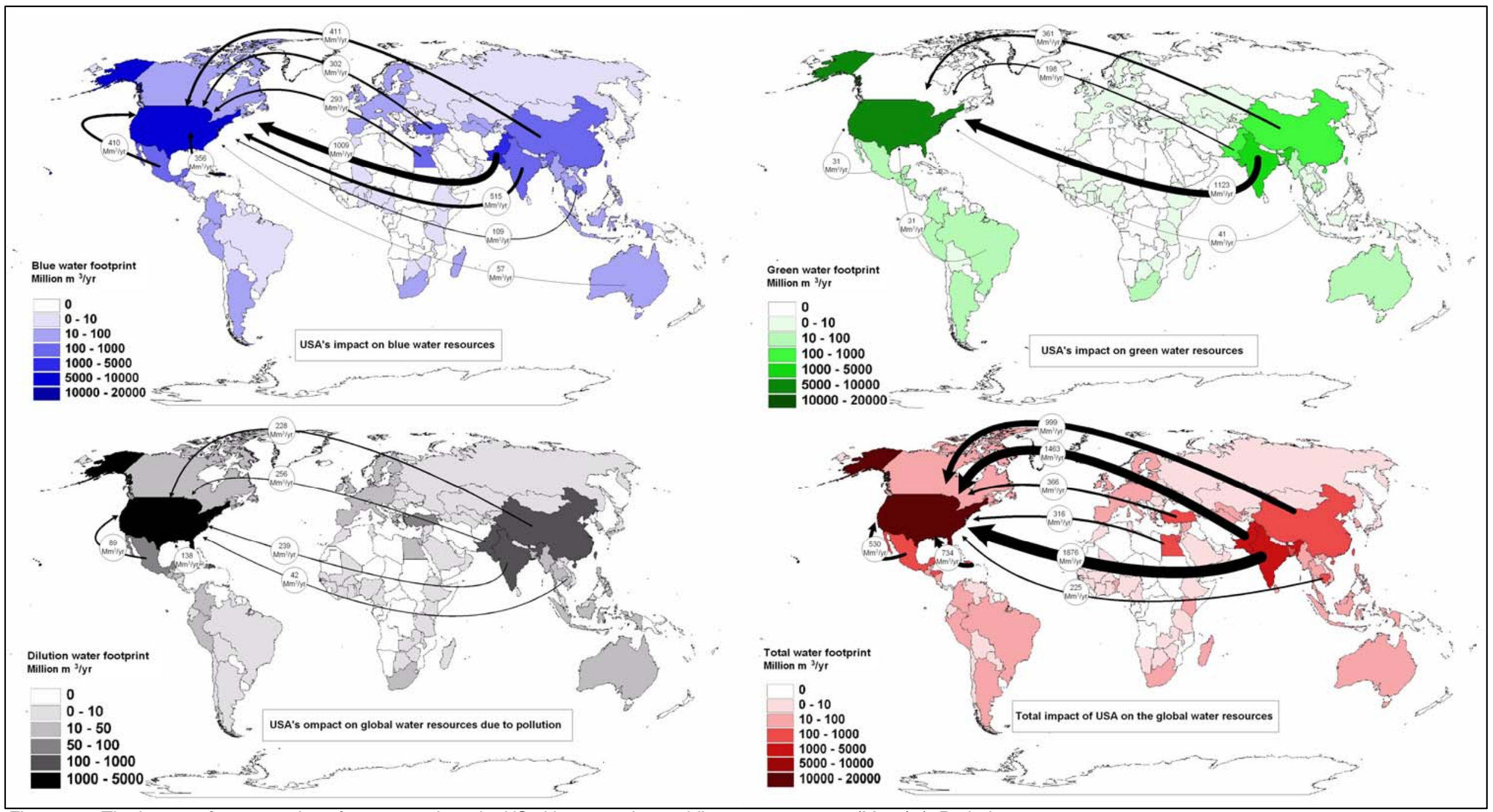

Figure 6.1. The impact of consumption of cotton products by US citizens on the world's water resources (Mm3/yr). Period: 1997-2001. 


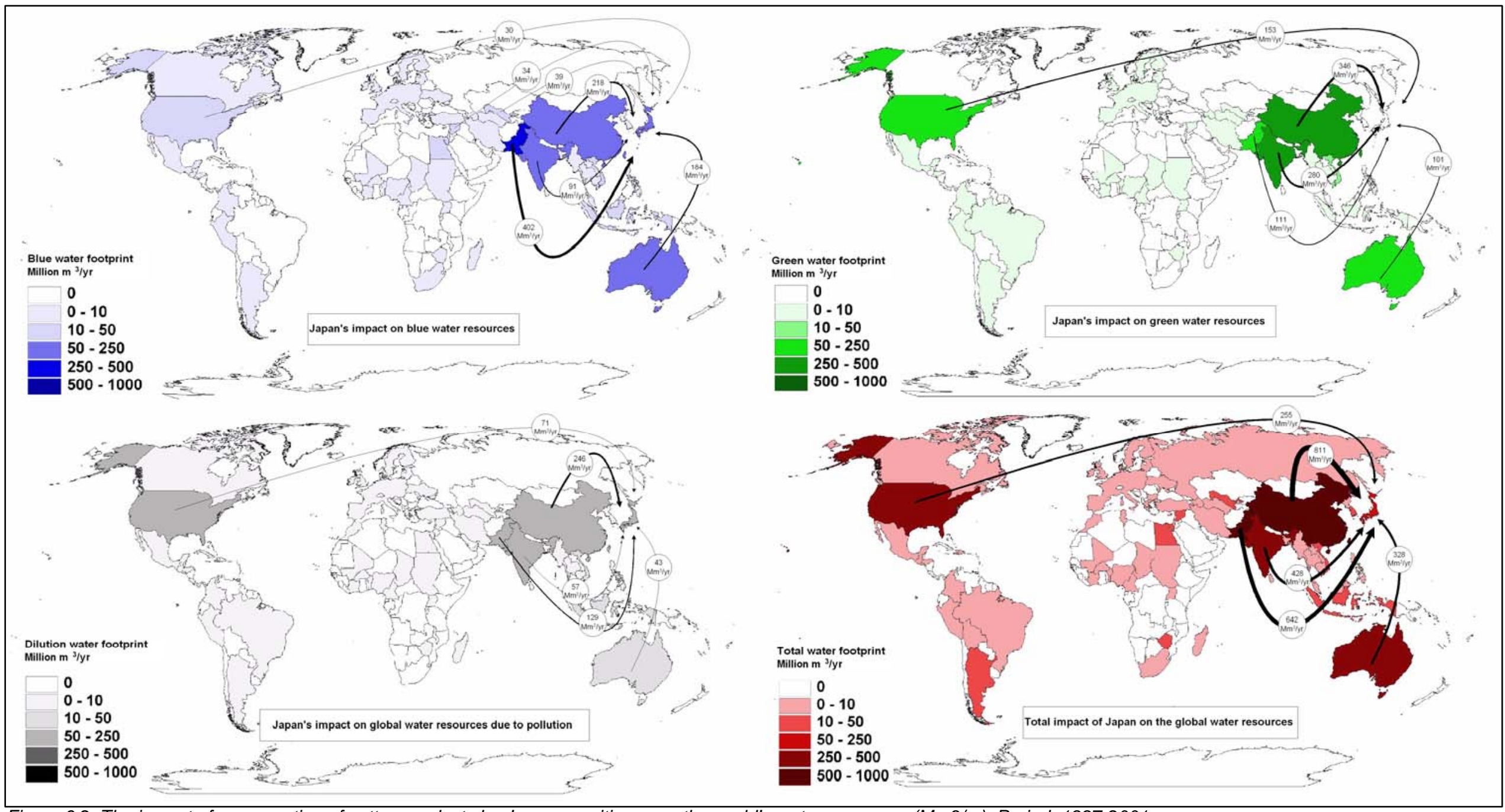

Figure 6.2. The impact of consumption of cotton products by Japanese citizens on the world's water resources (Mm3/yr). Period: 1997-2001. 


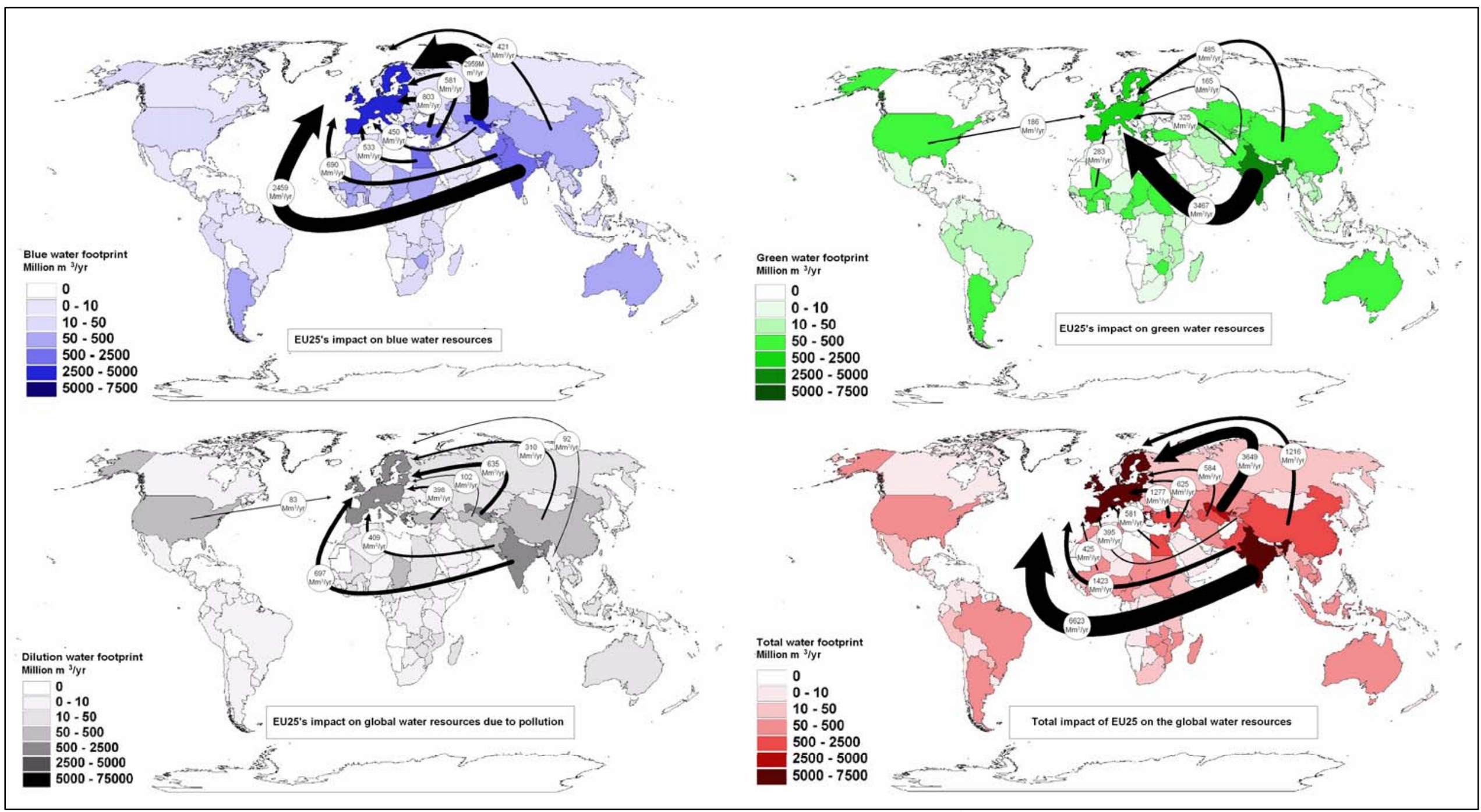

Figure 6.3. The impact of consumption of cotton products by the people in EU25 on the world's water resources (Mm3/yr). Period: 1997-2001. 


\section{Conclusion}

The authors believe that a single indicator of sustainability does not exist, because of the variety of facts, values and uncertainties that play a role in any debate of sustainable development. The water footprint of a nation should clearly not be seen as the ultimate indicator of sustainability, but rather as a new indicator that can add to the sustainability debate. It adds to the ecological footprint and the embodied energy concept by taking water as a central viewpoint as alternative to land or energy. It adds to earlier indicators of water use by taking the consumer's perspective on water use instead of the producer's perspective.

After the introduction of the ecological footprint concept in the 1990s, several scholars have expressed doubts whether the concept is useful in science or policy making. At the same time we see that the concept attracts attention and evokes scientific debate. We expect that the water footprint concept leads to a similar dual response. On the one hand the water footprint does not do else than gathering and presenting known data in a new format and as such does not add new knowledge. On the other hand, the water footprint adds a new fruitful perspective on issues such as water scarcity, water dependency, sustainable water use, and the implications of global trade for water management.

For water managers, water management is a river basin or catchment issue (see for instance the new South African National Water Act, 1998, and the new European Water Framework Directive, 2000). The water footprint, showing the use of water in foreign countries, shows that it is not sufficient to stick to that scale. Water problems in the major cotton producing areas of the world cannot be solved without addressing the global issue that consumers are not being held responsible for some of the economic costs and ecological impacts, which remain in the producing areas. The water footprint shows water use from the consumer's perspective, while traditional statistics show water use from the producer's perspective. This makes it possible to compare the water demand for North American or European citizens with the water demand for people in Africa, India or China. In the context of equitability and sustainability, this is a more useful comparison than a comparison between the actual water use in the USA or Europe with the actual water use in an African or Asian country, simply because the actual water use tells something about production but not about consumption.

The water footprint shows how dependent many nations are on the water resources in other countries. For its consumption of cotton products, the EU25 is very much dependent on the water resources in other continents, particularly water in Asia as this study shows, but also for other products there is a strong dependence on water resources outside Europe (Chapagain and Hoekstra, 2004). This means that water in Europe is scarcer than current indicators (showing water abstractions within Europe in relation to the available water resources within Europe) do suggest.

Cotton consumption is responsible for 2.6 per cent of the global water use. As a global average, 44 per cent of the water use for cotton growth and processing is not for serving the domestic market but for export. This means that - roughly spoken - nearly half of the water problems in the world related to cotton growth and processing 
can be attributed to foreign demand for cotton products. By looking at the trade relations, it is possible to track down the location of the water footprint of a community or, in other words, to link consumption at one place to the impacts at another place. The study for instance shows that the consumers in the EU25 countries indirectly contribute for about 20 per cent to the desiccation of the Aral Sea. Visualizing the actual but hidden link between cotton consumers and the water impacts of cotton production is a relevant issue in the light of the fact that the economic and environmental externalities of water use are generally not included in the price of the cotton products paid by the foreign consumers. Including information about the water footprint in product information, be it in the form of pricing or product labelling, is thus a crucial aspect in policy aimed at the reduction of negative externalities as water depletion and pollution. Given the global character of the cotton market, international cooperation in setting the rules for cotton trade is a precondition.

Since each component of the total water footprint includes a certain economic cost and environmental impact, it would be useful to see which of the costs and impacts are transferred to the consumer. In this study we have not done a careful examination of that, but there is quite some evidence that the majority of costs and impacts of water use and pollution caused in agriculture and industry is not translated into the price of products. According to the World Bank, the economic cost recovery in developing countries in the water sector is about 25 per cent (Serageldin, 1995). Social and environmental impacts of water use are generally not translated into the price of products at all, with sometimes an exception for the costs made for wastewater treatment before disposal. Most of the global waste flows are not treated however. Although a few industrialised countries achieve a wastewater treatment coverage of nearly 100 per cent, this coverage remains below five per cent in most developing countries (Eurostat, 2005; Hoekstra, 1998). Besides, the hundred per cent waste coverage in some of the industrialised countries refers to treatment of concentrated waste flows from households and industries only, but excludes the diffuse waste flow in agriculture. Given the general lack of proper water pricing mechanisms or other ways of transmitting production-information, cotton consumers have little incentive to take responsibility for the impacts on remote water systems.

About one fifth of the global water footprint due to cotton consumption is related to the pollution. This estimate is based on the assumption that wastewater flows can be translated into a certain water requirement for dilution based on water quality standards. Implicitly we have assumed here that the majority of waste flows enters natural water bodies without prior treatment, which is certainly true for leaching of fertilisers in agriculture and largely true for waste flows from cotton industries. In some of the rich countries, however, there is often treatment of waste flows from industries before disposal, so that we have got an overestimate of dilution water requirements here. In case of treatment of waste flows to the extent that the effluents meet water quality standards, a better estimate for the water requirement would be to consider the actual water use for the treatment process. Another issue is that we did not account for natural background concentrations in dilution water, so that we have got a conservative estimate for the required dilution volume. We also have made a conservative estimate by looking at the dilution volume required for fertilisers, but not at the volume for diluting pesticides used. 


\section{References}

Allan, J.A. (1997) 'Virtual water: A long term solution for water short Middle Eastern economies?’ Paper presented at the 1997 British Association Festival of Science, University of Leeds, 9 September 1997.

Allan, J.A. (1998) 'Virtual water: A strategic resource, global solutions to regional deficits’, Groundwater 36 (4), 545-546.

Chapagain, A.K. and Hoekstra, A.Y. (2003a) 'Virtual water flows between nations in relation to trade in livestock and livestock products', Value of Water Research Report Series No. 13, UNESCO-IHE, Delft, the Netherlands.

Chapagain, A.K. and Hoekstra, A.Y. (2003b) 'The water needed to have the Dutch drink coffee', Value of Water Research Report Series No. 14, UNESCO-IHE, Delft, the Netherlands.

Chapagain, A.K. and Hoekstra, A.Y. (2004) 'Water footprints of nations', Value of Water Research Report Series No. 16, UNESCO-IHE, Delft, the Netherlands.

Cotton Australia (2005) 'How to grow a pair of Jeans’, www.cottonaustralia.com.au.

CCI (2005) ‘Regions of US productions’, Cotton Council International.

CRC (2004) ‘NUTRIpak: A practical guide to cotton nutrition’, Australian Cotton Cooperative Research Centre.

De Man, R. (2001) 'The global cotton and textile chain: Substance flows, actors and co-operation for sustainability', A study in the framework of WWF's Freshwater and Cotton Programme, Reinier de Man Publications, Leiden, the Netherlands.

EPA (2005) 'List of drinking water contaminants: Ground water and drinking water', US Environmental Protection Agency.

Eurostat (2005), Web page of EU Statistical Office, Luxembourg, http://epp.eurostat.cec.eu.int.

Falkenmark, M. (1995) 'Land-water linkages: a synopsis’ In: Land and Water Integration and River Basin Management, FAO, Rome, pp. 15-16.

FAO (1999) 'Irrigation in Asia in Figures', Water Reports 18, Food and Agriculture Organization, Rome, Italy.

FAO (2003a) ‘CROPWAT model’, Food and Agriculture Organization, Rome, Italy.

FAO (2003b) 'FAOCLIM: a CD-ROM with world-wide agroclimatic data', Food and Agriculture Organization, Rome, Italy.

FAO (2003c) ‘CLIMWAT database’, Food and Agriculture Organization, Rome, Italy.

FAO (2003d) ‘Technical Conversion Factors for Agricultural Commodities’, Food and Agriculture Organization, Rome, Italy. 
FAO (2005) 'Review of global agricultural water use per country', crop water requirements, Food and Agriculture Organization, Rome, Italy.

FAOSTAT (2004) Web page of Food and Agriculture Organization, Rome, Italy, http://faostat.fao.org.

Gillham, F.E.M., Bell, T.M., Arin, T., Matthews, T.A., Rumeur, C.L. and Hearn A.B. (1995) 'Cotton production prospects for the next decade', World Bank Technical Paper Number 287, the World Bank, Washington D.C.

Glantz, M. H. (1998) 'Creeping environmental problems in the Aral Sea basin. In: I. Kobori and M. H. Glantz (eds.) Central Eurasian water crisis: Caspian, Aral and dead seas, United Nations University Press, New York.

Hall, M., Dixon, J., Gulliver, A. and Gibbon, D., (eds.) (2001) 'Farming systems and poverty: Improving farmer's livelihoods in a changing world', FAO and World Bank, Rome and Washington.

Herendeen, R.A. (2004) ‘Energy analysis and EMERGY analysis - A comparison’, Ecol. Model., 178, $227-237$.

Hoekstra, A.Y. (1998) 'Perspectives on water: A model-based exploration of the future’, International Books, Utrecht, the Netherlands.

Hoekstra, A.Y. and Hung, P.Q. (2002) 'Virtual water trade: A quantification of virtual water flows between nations in relation to international crop trade', Value of Water Research Report Series No. 11, UNESCO-IHE, Delft, the Netherlands

Hoekstra, A.Y. and Hung, P.Q. (2005) 'Globalisation of water resources: international virtual water flows in relation to crop trade', Global Environ. Chang. 15(1), 45-56.

IFA, IFDC, IPI, PPI and FAO (2002) ‘Fertilizer use by crop’, Food and Agriculture Organization, Rome, Italy.

ITC (2004) 'PC-TAS version 1997-2001 in HS or SITC’, CD-ROM, International Trade Centre, Geneva.

Loh, J. and Wackernagel, M. (2004) 'Living planet report 2004', WWF, Gland, Switzerland.

Pereira, L. S., Cordery, I. and Iacovides, I. (2002) 'Coping with water scarcity’, International Hydrological Programme, UNESCO, Paris.

Postel, S. (1992) 'Last oasis: Facing water scarcity’, W.W Norton \& Company, New York.

Postel, S.L., Daily, G.C., and Ehrlich, P.R. (1996) 'Human appropriation of renewable fresh water', Science 271, 785-788.

Proto, M., Supino, S., and Malandrino, O. (2000) ‘Cotton: a flow cycle to exploit’, Ind. Crop. Prod. 11(2-3), 173-178.

Rees, W.E. (1992) 'Ecological footprints and appropriated carrying capacity: what urban economics leaves out', Environ. Urban. 4(2), 121-130. 
Ren, X. (2000) 'Development of environmental performance indicators for textile process and product', Journal of Cleaner Production, 8(6), 473-481.

Serageldin, I. (1995) 'Water resources management: a new policy for a sustainable future’, Wat. Int. 20(1), 1521.

Seuring, S. (2004) 'Integrated chain management and supply chain management: Comparative analysis and illustrative cases', Journal of Cleaner Production 12: 1059-1071.

Silvertooth, J.C, Navarro, J.C., Norton, E.R. Galadima, A. (2001) 'Soil and plant recovery of labeled fertilizer nitrogen in irrigated cotton', Arizona Cotton Report, University of Arizona.

Soth, J., Grasser, C., and Salerno, R. (1999) 'The impact of cotton on fresh water resources and ecosystems: A preliminary analysis’, WWF, Gland, Switzerland.

UNCTAD (2005a) 'Planting and harvesting times for cotton, by producing country’, http://r0.unctad.org/infocomm/anglais/cotton/crop.htm.

UNCTAD, 2005b. Cotton uses, http://r0.unctad.org/infocomm/anglais/cotton/uses.htm

UNEP (2002) ‘Global environment outlook 3: Past, present and future perspectives’, Earthscan Publications, London.

UNEP IE (1996) ‘Cleaner production in textile wet processing: a workbook for trainers’, United Nations Environment Programme: Industry and Environment, Paris.

USDA (2004) ‘Cotton: World markets and trade’, http://www.fas.usda.gov/cotton/circular/2004/07/CottonWMT.pdf USDA/NOAA (2005a) 'Major world crop areas and climatic profiles’, USDA/NOAA Joint Agricultural Weather Facility, http://www.usda.gov/agency/oce/waob/mississippi/MajorWorldCropAreas.pdf.

USDA/NOAA (2005b) ‘Cotton - World supply and demand summary’, USDA/NOAA Joint Agricultural Weather Facility, http://www.tradefutures.cc/education/cotton/worldsd.htm.

USEPA (1996) ‘Best management practices for pollution prevention in the textile industry’, www.e-textile.org. Van den Bergh, J.C.J.M. and Verbruggen, H. (1999) 'Spatial sustainability, trade and indicators: An evaluation of the 'ecological footprint', Ecol. Econ. 29, 61-72.

Van Kooten, G.C. and Bulte, E.H. (2000) 'The ecological footprint: useful science or politics’, Ecol. Econ. 32, 385-389.

Visvanathan, C., Kumar, S. and Han, S. (2000) ‘Cleaner production in textile sector: Asian scenario’, Paper presented at the 'National Workshop on Sustainable Industrial Development through Cleaner Production', 12-13 November, Colombo, Sri Lanka. 
Wackernagel, M. and Rees, W. (1996) ‘Our ecological footprint: Reducing human impact on the earth’, New Society Publishers, Gabriola Island, B.C., Canada.

Wackernagel, M., Onisto, L., Linares, A.C., Falfan, I.S.L., Garcia, J.M., Guerrero, I.S., and Guerrero, M.G.S. (1997) 'Ecological footprints of nations: How much nature do they use? - How much nature do they have?' Centre for Sustainability Studies, Universidad Anahuac de Xalapa, Mexico.

Wackernagel, M., Onisto, L., Bello, P., Linares, A.C., Falfan, I.S.L., Garcia, J.M., Guerrero, A.I.S., and Guerrero, M.G.S. (1999) 'National natural capital accounting with the ecological footprint concept', Ecol. Econ. 29, 375-390.

WB (1999) ‘Pollution prevention and abatement handbook 1998: Toward cleaner production’, World Bank, Washington D.C.

WWF (2003) ‘Thirsty crops: Our food and clothes: Eating up nature and wearing out the environment?’ Living waters: conserving the source of life, WWF, The Netherlands. 
Appendix I. The composition, per country, of the water footprint related to the consumption of cotton products. Period: 1997-2001.

\begin{tabular}{|c|c|c|c|c|c|c|c|c|c|}
\hline & \multicolumn{4}{|c|}{ Internal water footprint $\left(\mathrm{Mm}^{3} / \mathrm{yr}\right)$} & \multicolumn{4}{|c|}{ External water footprint $\left(\mathrm{Mm}^{3} / \mathrm{yr}\right)$} & \multirow{2}{*}{$\begin{array}{c}\text { Total } \\
\left(\mathrm{Mm}^{3} / \mathrm{yr}\right)\end{array}$} \\
\hline & Blue & Green & Dilution & Total & Blue & Green & Dilution & Total & \\
\hline Albania & 1 & 0 & 1 & 3 & 27 & 16 & 10 & 52 & 55 \\
\hline Algeria & 7 & 0 & 13 & 20 & 133 & 63 & 33 & 229 & 249 \\
\hline Angola & 21 & 19 & 10 & 51 & 0 & 0 & 0 & 0 & 51 \\
\hline Argentina & 832 & 1953 & 156 & 2940 & 22 & 89 & 20 & 131 & 3071 \\
\hline Australia & 755 & 585 & 296 & 1637 & 234 & 294 & 164 & 691 & 2328 \\
\hline Austria & 6 & 0 & 11 & 17 & 395 & 169 & 133 & 696 & 713 \\
\hline Azerbaijan & 46 & 34 & 30 & 110 & 2 & 1 & 1 & 3 & 113 \\
\hline Bahamas & 1 & 0 & 1 & 1 & 9 & 20 & 11 & 40 & 41 \\
\hline Bangladesh & 4 & 29 & 44 & 77 & 20 & 587 & 79 & 687 & 764 \\
\hline Barbados & 0 & 0 & 0 & 0 & 1 & 3 & 1 & 6 & 6 \\
\hline Belarus & 8 & 0 & 14 & 22 & 144 & 32 & 37 & 213 & 234 \\
\hline Belgium-Luxembourg & 15 & 0 & 25 & 41 & 1215 & 763 & 395 & 2373 & 2414 \\
\hline Benin & 200 & 209 & 85 & 494 & 10 & 19 & 6 & 36 & 530 \\
\hline Bhutan & 0 & 0 & 0 & 0 & 2 & 6 & 1 & 9 & 9 \\
\hline Bolivia & 83 & 98 & 45 & 227 & 74 & 502 & 105 & 681 & 908 \\
\hline Botswana & 7 & 5 & 5 & 16 & 25 & 26 & 10 & 60 & 77 \\
\hline Brazil & 404 & 3454 & 804 & 4662 & 1451 & 1643 & 369 & 3464 & 8126 \\
\hline Brunei & 2 & 0 & 3 & 5 & 58 & 59 & 29 & 146 & 151 \\
\hline Burkina Faso & 284 & 258 & 136 & 679 & 0 & 0 & 0 & 0 & 679 \\
\hline Burundi & 4 & 4 & 2 & 10 & 1 & 2 & 1 & 3 & 13 \\
\hline Cameroon & 88 & 85 & 37 & 211 & 1 & 1 & 0 & 2 & 213 \\
\hline Canada & 39 & 0 & 86 & 125 & 592 & 1204 & 478 & 2274 & 2399 \\
\hline Central African Rep. & 18 & 17 & 8 & 43 & 0 & 0 & 0 & 0 & 43 \\
\hline Chad & 123 & 118 & 50 & 291 & 0 & 0 & 0 & 0 & 291 \\
\hline Chile & 8 & 0 & 14 & 22 & 134 & 302 & 50 & 486 & 507 \\
\hline China & 8775 & 11176 & 6585 & 26536 & 10738 & 10213 & 4485 & 25436 & 51972 \\
\hline Colombia & 174 & 160 & 115 & 449 & 170 & 357 & 98 & 625 & 1074 \\
\hline Congo, DR & 56 & 50 & 28 & 134 & 0 & 0 & 0 & 0 & 134 \\
\hline Côte d'Ivoire & 189 & 198 & 74 & 462 & 5 & 12 & 2 & 20 & 481 \\
\hline Croatia & 2 & 0 & 3 & 5 & 59 & 43 & 18 & 120 & 125 \\
\hline Cyprus & 0 & 0 & 1 & 1 & 23 & 21 & 10 & 55 & 55 \\
\hline Czech Republic & 15 & 0 & 23 & 38 & 392 & 113 & 104 & 609 & 647 \\
\hline Denmark & 5 & 0 & 9 & 14 & 221 & 207 & 96 & 524 & 538 \\
\hline Ecuador & 15 & 12 & 15 & 42 & 29 & 60 & 25 & 115 & 157 \\
\hline Egypt & 1433 & 0 & 177 & 1610 & 60 & 193 & 25 & 278 & 1888 \\
\hline Equatorial Guinea & 8 & 0 & 14 & 22 & 0 & 0 & 0 & 0 & 22 \\
\hline Estonia & 7 & 0 & 12 & 19 & 307 & 49 & 81 & 437 & 455 \\
\hline Ethiopia & 79 & 74 & 35 & 189 & 4 & 3 & 2 & 8 & 197 \\
\hline Finland & 0 & 0 & 1 & 1 & 67 & 70 & 31 & 167 & 168 \\
\hline France & 53 & 0 & 93 & 146 & 2387 & 1576 & 867 & 4831 & 4977 \\
\hline Gambia & 2 & 1 & 2 & 4 & 9 & 14 & 4 & 28 & 32 \\
\hline Germany & 47 & 0 & 79 & 126 & 3525 & 2049 & 1220 & 6794 & 6920 \\
\hline Ghana & 45 & 41 & 23 & 109 & 9 & 10 & 4 & 24 & 133 \\
\hline Greece & 1199 & 416 & 382 & 1997 & 278 & 266 & 115 & 660 & 2657 \\
\hline Guinea & 74 & 69 & 37 & 180 & 17 & 26 & 11 & 54 & 234 \\
\hline Hungary & 8 & 0 & 13 & 21 & 232 & 118 & 74 & 424 & 444 \\
\hline Iceland & 0 & 0 & 0 & 0 & 5 & 5 & 2 & 12 & 12 \\
\hline India & 7015 & 19462 & 3965 & 30441 & 281 & 222 & 81 & 583 & 31024 \\
\hline Indonesia & 86 & 18 & 152 & 256 & 773 & 683 & 330 & 1786 & 2042 \\
\hline Iran & 789 & 731 & 353 & 1874 & 32 & 4 & 7 & 43 & 1917 \\
\hline
\end{tabular}




\begin{tabular}{|c|c|c|c|c|c|c|c|c|c|}
\hline & \multicolumn{4}{|c|}{ Internal water footprint $\left(\mathrm{Mm}^{3} / \mathrm{yr}\right)$} & \multicolumn{4}{|c|}{ External water footprint $\left(\mathrm{Mm}^{3} / \mathrm{yr}\right)$} & \multirow{2}{*}{$\begin{array}{c}\text { Total } \\
\left(\mathrm{Mm}^{3} / \mathrm{yr}\right)\end{array}$} \\
\hline & Blue & Green & Dilution & Total & Blue & Green & Dilution & Total & \\
\hline Ireland & 5 & 0 & 10 & 15 & 198 & 196 & 86 & 481 & 496 \\
\hline Israel & 124 & 124 & 72 & 320 & 452 & 814 & 241 & 1508 & 1828 \\
\hline Italy & 83 & 0 & 106 & 189 & 2254 & 644 & 465 & 3363 & 3552 \\
\hline Japan & 78 & 0 & 165 & 244 & 1696 & 1735 & 935 & 4366 & 4610 \\
\hline Jordan & 1 & 0 & 2 & 3 & 48 & 19 & 13 & 79 & 82 \\
\hline Kazakhstan & 174 & 169 & 68 & 411 & 0 & 0 & 0 & 1 & 412 \\
\hline Kenya & 26 & 29 & 12 & 67 & 23 & 45 & 11 & 79 & 146 \\
\hline Korea, DPR & 64 & 59 & 30 & 153 & 0 & 0 & 0 & 0 & 153 \\
\hline Korea, Rep. & 124 & 0 & 224 & 348 & 1808 & 1538 & 648 & 3994 & 4343 \\
\hline Kyrgyzstan & 55 & 54 & 20 & 129 & 0 & 0 & 0 & 0 & 129 \\
\hline Laos & 5 & 5 & 1 & 11 & 0 & 0 & 0 & 0 & 11 \\
\hline Lebanon & 2 & 0 & 3 & 5 & 57 & 60 & 19 & 136 & 141 \\
\hline Lithuania & 1 & 0 & 2 & 3 & 31 & 22 & 10 & 63 & 66 \\
\hline Malawi & 46 & 45 & 17 & 108 & 0 & 0 & 0 & 0 & 108 \\
\hline Malaysia & 36 & 0 & 68 & 105 & 609 & 686 & 262 & 1557 & 1662 \\
\hline Maldives & 2 & 0 & 4 & 7 & 84 & 229 & 47 & 361 & 368 \\
\hline Mali & 241 & 573 & 80 & 894 & 1 & 1 & 1 & 3 & 897 \\
\hline Malta & 2 & 0 & 3 & 4 & 56 & 28 & 15 & 99 & 103 \\
\hline Mauritius & 10 & 0 & 21 & 31 & 117 & 456 & 59 & 632 & 663 \\
\hline Mexico & 460 & 327 & 549 & 1336 & 1297 & 5395 & 2489 & 9181 & 10517 \\
\hline Mozambique & 50 & 46 & 23 & 119 & 0 & 0 & 0 & 0 & 119 \\
\hline Myanmar & 228 & 214 & 100 & 542 & 0 & 0 & 0 & 0 & 542 \\
\hline Namibia & 8 & 7 & 4 & 19 & 0 & 0 & 0 & 0 & 19 \\
\hline Nepal & 3 & 1 & 4 & 8 & 39 & 181 & 26 & 245 & 253 \\
\hline Netherlands & 22 & 0 & 39 & 61 & 1277 & 1035 & 539 & 2850 & 2912 \\
\hline New Zealand & 4 & 0 & 7 & 12 & 157 & 147 & 74 & 378 & 389 \\
\hline Niger & 12 & 10 & 7 & 29 & 5 & 5 & 2 & 12 & 41 \\
\hline Nigeria & 658 & 613 & 311 & 1583 & 93 & 200 & 48 & 341 & 1924 \\
\hline Norway & 2 & 0 & 3 & 5 & 157 & 148 & 73 & 378 & 383 \\
\hline Pakistan & 9672 & 2567 & 3012 & 15251 & 0 & 0 & 0 & 0 & 15251 \\
\hline Papua New Guinea & 0 & 0 & 0 & 0 & 7 & 6 & 3 & 15 & 16 \\
\hline Paraguay & 147 & 156 & 55 & 358 & 3 & 10 & 2 & 15 & 373 \\
\hline Peru & 138 & 145 & 78 & 361 & 64 & 130 & 32 & 226 & 587 \\
\hline Philippines & 14 & 2 & 25 & 41 & 160 & 222 & 75 & 457 & 498 \\
\hline Poland & 34 & 0 & 55 & 88 & 769 & 274 & 215 & 1258 & 1347 \\
\hline Portugal & 39 & 0 & 54 & 93 & 449 & 235 & 102 & 787 & 880 \\
\hline Russian Federation & 84 & 0 & 143 & 227 & 2076 & 74 & 496 & 2646 & 2874 \\
\hline Saudi Arabia & 1 & 0 & 2 & 4 & 175 & 99 & 64 & 338 & 342 \\
\hline Senegal & 15 & 21 & 8 & 44 & 5 & 15 & 3 & 23 & 67 \\
\hline Serbia \& Montenegro & 1 & 0 & 2 & 3 & 103 & 17 & 23 & 143 & 147 \\
\hline Singapore & 17 & 0 & 31 & 47 & 708 & 857 & 361 & 1926 & 1974 \\
\hline Slovakia & 4 & 0 & 6 & 9 & 81 & 34 & 25 & 140 & 150 \\
\hline Slovenia & 2 & 0 & 3 & 6 & 87 & 36 & 23 & 146 & 152 \\
\hline South Africa & 80 & 80 & 47 & 207 & 114 & 155 & 46 & 316 & 523 \\
\hline Spain & 387 & 325 & 173 & 885 & 693 & 518 & 232 & 1443 & 2328 \\
\hline Sudan & 209 & 208 & 75 & 492 & 2 & 1 & 1 & 4 & 496 \\
\hline Swaziland & 39 & 34 & 20 & 93 & 16 & 16 & 7 & 39 & 132 \\
\hline Sweden & 2 & 0 & 4 & 6 & 306 & 304 & 145 & 755 & 761 \\
\hline Switzerland & 0 & 0 & 1 & 1 & 70 & 101 & 53 & 224 & 225 \\
\hline Syria & 1736 & 45 & 166 & 1947 & 0 & 0 & 0 & 0 & 1947 \\
\hline Tajikistan & 349 & 345 & 127 & 821 & 0 & 0 & 0 & 0 & 821 \\
\hline Tanzania & 138 & 137 & 58 & 333 & 5 & 10 & 3 & 18 & 351 \\
\hline
\end{tabular}


Water footprint of cotton consumption / 39

\begin{tabular}{|c|c|c|c|c|c|c|c|c|c|}
\hline & \multicolumn{4}{|c|}{ Internal water footprint $\left(\mathrm{Mm}^{3} / \mathrm{yr}\right)$} & \multicolumn{4}{|c|}{ External water footprint $\left(\mathrm{Mm}^{3} / \mathrm{yr}\right)$} & \multirow{2}{*}{$\begin{array}{c}\text { Total } \\
\left(\mathrm{Mm}^{3} / \mathrm{yr}\right)\end{array}$} \\
\hline & Blue & Green & Dilution & Total & Blue & Green & Dilution & Total & \\
\hline Thailand & 106 & 42 & 136 & 285 & 690 & 766 & 243 & 1699 & 1984 \\
\hline Togo & 123 & 120 & 54 & 297 & 12 & 15 & 6 & 32 & 330 \\
\hline Trinidad \& Tobago & 0 & 0 & 0 & 0 & 6 & 8 & 4 & 19 & 19 \\
\hline Turkey & 3754 & 508 & 1172 & 5434 & 1453 & 1106 & 482 & 3042 & 8476 \\
\hline Turkmenistan & 3958 & 287 & 897 & 5141 & 1 & 0 & 0 & 2 & 5143 \\
\hline Uganda & 79 & 74 & 31 & 185 & 17 & 8 & 6 & 31 & 216 \\
\hline UK & 35 & 0 & 62 & 97 & 2307 & 2175 & 980 & 5463 & 5560 \\
\hline Uruguay & 0 & 0 & 1 & 1 & 9 & 36 & 4 & 50 & 51 \\
\hline USA & 5111 & 9314 & 4971 & 19397 & 9429 & 5738 & 3216 & 18383 & 37780 \\
\hline Uzbekistan & 6956 & 131 & 1598 & 8685 & 0 & 0 & 0 & 0 & 8685 \\
\hline Venezuela & 75 & 60 & 50 & 185 & 167 & 215 & 88 & 470 & 654 \\
\hline Yemen & 42 & 39 & 19 & 100 & 0 & 0 & 0 & 0 & 100 \\
\hline Zambia & 41 & 38 & 17 & 96 & 4 & 3 & 2 & 8 & 104 \\
\hline Zimbabwe & 158 & 155 & 60 & 374 & 0 & 0 & 0 & 0 & 374 \\
\hline World & 59605 & 54793 & 28515 & 142914 & 48025 & 44655 & 20743 & 113423 & 256336 \\
\hline
\end{tabular}




UNESCO-IHE

P.O. Box 3015

2601 DA Delft

The Netherlands

Website www.unesco-ihe.org

Phone +31152151715

Institute for Governance Studies

University of Twente
UNESCO-IHE

Institute for Water Education
IGS

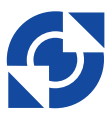

University of Twente The Netherlands 